\title{
9. FORAMINIFERS OF THE MIDDLE AMERICA TRENCH ${ }^{1}$
}

\author{
Peter R. Thompson, ${ }^{2}$ Lamont-Doherty Geological Observatory of Columbia University, Palisades, New York
}

\begin{abstract}
During Deep Sea Drilling Project Leg 67, fifteen holes were drilled at seven sites, forming a north-south transect across the Middle America Trench and slope off Guatemala. Lower Miocene (N4) chalk was found in contact with basement at three sites on the subducting Cocos Plate, in contrast with the sandy hemipelagic mudstones of the same age found at the four lower slope sites. Unconformities are present between the Maestrichtian and middle Eocene, middle Eocene and lower Miocene, and possibly middle Miocene and upper Miocene at Site 494. The absence of chalk on the landward side of the Trench indicates that subduction rather than accretion has been the dominant tectonic process since the Miocene.

Downslope displacement of sediment appears to be more prevalent on the lower slope than simple pelagic and hemipelagic sedimentation. Planktonic foraminifers and benthic formaminifers are generally too well-preserved for the locations below the CCD, and benthic foraminifers are more typical of shallower water depth. The displacement of the foraminifers is apparently contemporaneous with initial deposition, because the planktonic foraminiferal biostratigraphy has not been disturbed or reversed. No in situ Trench fauna has developed, because the Trench is presently being filled with turbidites funneled past the slope by a large submarine canyon near San José, Guatemala.

Preliminary offshore-onshore biostratigraphic correlations between Leg 67 sites and sedimentary sections of Guatemala, Costa Rica, and the Panama Canal Zone reveal similar unconformities and periods of deposition throughout the region. These gaps may represent times of episodic subduction of the oceanic plate and the gradual development of an imbricate stack as new oceanic pieces were added to the underside of the slope, causing periodic uplift.
\end{abstract}

\section{INTRODUCTION}

DSDP Leg 67 started in Manzanillo, Mexico, on May 9, 1979, and ended at Puntarenas, Costa Rica, on June 25,1979 . Fifteen holes were drilled at seven sites along a transect offshore of Guatemala (Fig. 1; Table 1). The westernmost site, Site 495 , was located on the eastern edge of the Cocos Plate, Sites 499 and 500 were placed in the Trench, Sites 494 and 498 were located at the base of the landward slope, and Sites 496 and 497 were placed near the Trench-slope break. The purpose of the transect was to study a convergent margin where accretion and imbrication may have been continuous during most of the Tertiary (Seely et al., 1974). Further, it was hoped that this leg would enable us to correlate offshore and onshore geology by studying modern and ancient sediment sequences in the Trench and on the slope.

Microfossils, including foraminifers, diatoms (Harper et al., this volume), radiolarians (Westberg and Rie$\mathrm{del}$, this volume), and calcareous nannoplankton (Muzylöv, this volume) were present at all sites. Barren intervals at some levels, however, complicated age resolution despite the good sediment recovery from the sites. In this study of foraminifers, a midcore and a corecatcher sample were examined for each core at all holes, and additional samples per core were taken to delimit important biostratigraphic horizons. The samples were washed to concentrate $63-\mu \mathrm{m}$-size fractions and weighed, although abundances are reported here from the 149$\mu \mathrm{m}$ fraction. Estimated abundances (rare, few, com-

\footnotetext{
${ }^{1}$ Aubouin, J., von Huene, R., et al., Init. Repts. DSDP, 67: Washington (U.S. Govt. Printing Office).

2 Present address: Arco Oil and Gas Company, Geological Research Department, PRC. Dallas, Texas.
}

mon, abundant, etc.) were determined for Sites 496,499 , and 500 (Tables 8,3 , and 4 , respectively), and relative abundances (number $/ 10-\mathrm{cm}^{3}$ sample) were specified for Sites 494, 495, 497, and 498 (Tables 5, 2, 7, and 6, respectively).

\section{BIOSTRATIGRAPHIC FRAMEWORK}

The low-latitude position of the Middle America Trench transect afforded an excellent micropaleontologic opportunity to investigate a convergent margin sedimentary sequence for two reasons. First, many groups of planktonic microfossils were present, permitting crosschecks on age determinations and facilitating greater biostratigraphic resolution. Second, the tropical location ensured high abundances and diversity within each group.

The planktonic foraminiferal biostratigraphy reported here for Leg 67 sites was constructed from several existing zonations (Fig. 2); no one of these zonations was completely applicable to all sites. The thick nannofossil chalks found at Site 495 (Fig. 3) were readily characterized by Blow (1969) as occurring in Zones N4 through $\mathrm{N} 13$, largely a modification of the earlier zonation by Bolli (1959, 1966). Upper Miocene and Pliocene hemipelagic sediments found in abundance at all sites, but particularly at Sites 496 and 497 (Figs. 9 and 10), were zoned using Eastern Equatorial Pacific schemes proposed by Jenkins and Orr (1972) and by Kaneps (1973). Long-term upwelling through the Quaternary apparently has modified the coastal fauna by excluding many of the more typical species used in Pleistocene biostratigraphy (see Thompson and Sciarrillo, 1978). For this reason, I have created a local zone typified by the total range of Neogloboquadrina eggeri, equivalent to the Pulleniatina obliquiloculata zone of Jenkins and Orr (1972) and Kaneps (1973). 


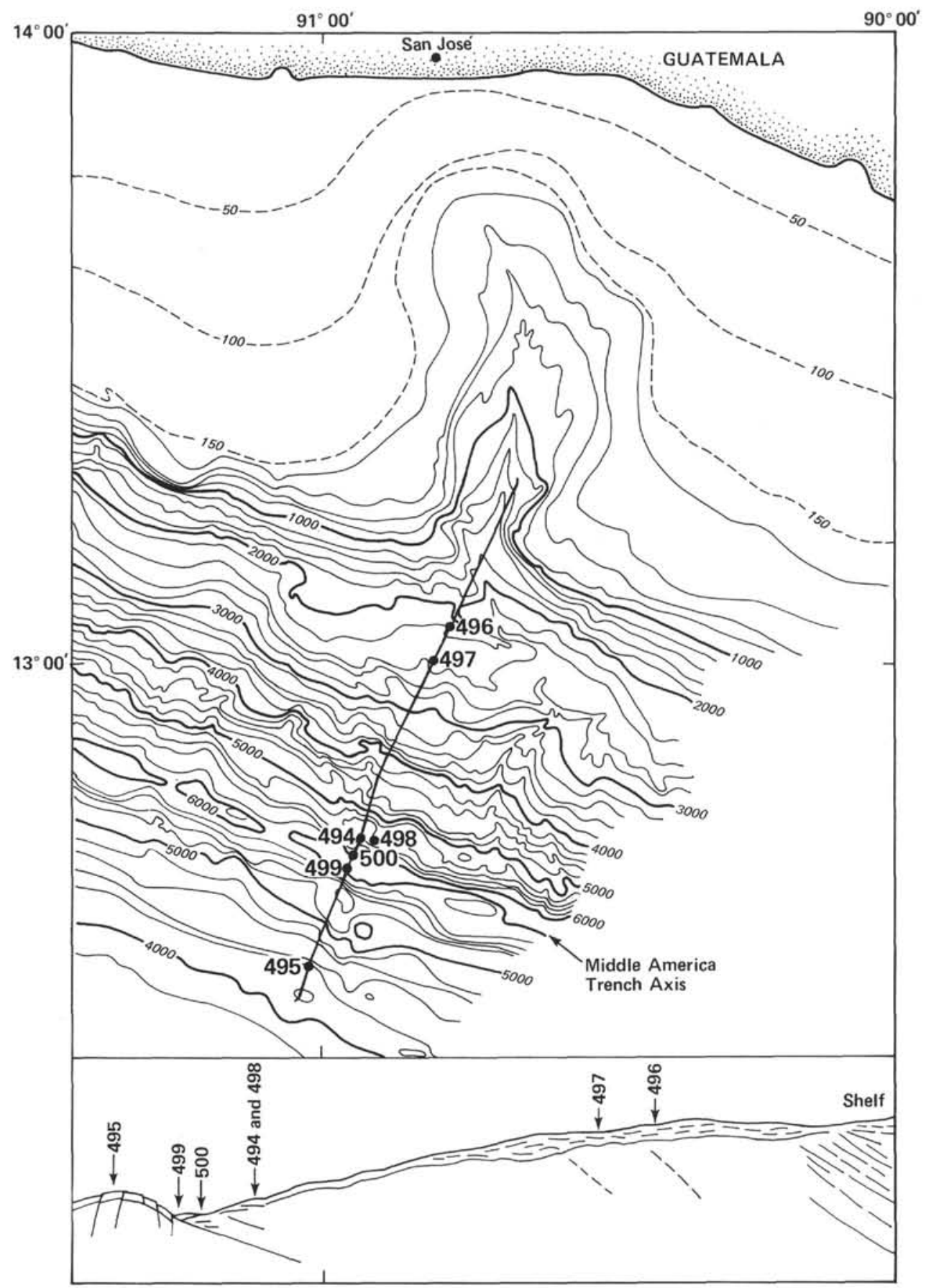

Figure 1. Location map of Leg 63 drill sites. (See Table 1 for locations.)

Short intervals of middle Eocene siltstone and Upper Cretaceous chalk were found at Hole 494A (Fig. 7). Both of these units were correlated with rocks of similar faunal composition described by Premoli Silva and Bolli (1973) from the Caribbean.

\section{Quaternary}

Rose Bengal stain was added to the top of the uppermost section at each drilling site and to all coarse fractions collected from "water cores" to identify any living foraminifers (a "water core" is an informal term em- ployed on the ship for those attempts at retrieving cores between the PDR (precision depth recorder) depth of the site and the mudline, i.e., sediment firm enough to be caught by the core catcher). In no case were any individuals found alive. Further, the uppermost foraminiferal assemblages found at Leg 67 sites were deposited in the late Pleistocene, not the Holocene. The youngest planktonic foraminiferal biostratigraphic event encountered in the upper Pleistocene is the Indo-Pacific extermination of pink-pigmented Globigerinoides ruber dated at about $120,000 \mathrm{yr}$. ago (Thompson et al., 1979). This 
Table 1. Site locations.

\begin{tabular}{|c|c|c|c|c|}
\hline Site & Latitude & Longitude & $\begin{array}{c}\text { Water } \\
\text { Depth }(m)\end{array}$ & Chronostratigraphy \\
\hline \multicolumn{5}{|l|}{ Leg 67} \\
\hline 494 & $12^{\circ} 43,00^{\prime} \mathrm{N}$ & $90^{\circ} 55.97 \mathrm{~W}$ & 5472 & Maestrichtian \\
\hline 495 & $12^{\circ} 29.78^{\prime} \mathrm{N}$ & $91^{\circ} 02.26^{\prime} \mathrm{W}$ & 4140 & Lower Miocene ${ }^{\mathrm{a}}$ \\
\hline 496 & $13^{\circ} 03.82^{\prime} \mathrm{N}$ & $90^{\circ} 47.71 \mathrm{~W}$ & 2049 & Lower Miocene \\
\hline 497 & $12^{\circ} 59.23 \mathrm{~N}$ & $90^{\circ} 49.68^{\prime} \mathrm{W}$ & 2347 & Upper Miocene \\
\hline 498 & $12^{\circ} 42.68^{\prime} \mathrm{N}$ & $90^{\circ} 54.94 \mathrm{~W}$ & 5478 & Lower Miocene \\
\hline 499 & $12^{\circ} 40.35^{\prime} \mathrm{N}$ & $90^{\circ} 56.65^{\prime} \mathrm{W}$ & 6105 & Lower Miocene ${ }^{\mathrm{a}}$ \\
\hline 500 & $12^{\circ} 41.05^{\prime} \mathrm{N}$ & $90^{\circ} 56.49^{\prime} \mathrm{W}$ & 6094 & Lower Miocene ${ }^{\mathrm{a}}$ \\
\hline \multicolumn{5}{|l|}{$\operatorname{Leg} 9$} \\
\hline 83 & $04^{\circ} 02.80^{\prime} \mathrm{N}$ & $95^{\circ} 44.25^{\circ} \mathrm{W}$ & 3632 & Middle Miocene ${ }^{a}$ \\
\hline 84 & $05^{\circ} 44.92^{\prime} \mathrm{N}$ & $82^{\circ} 53.29^{\prime} \mathrm{W}$ & 3097 & Upper Miocene ${ }^{\mathrm{a}}$ \\
\hline \multicolumn{5}{|l|}{ Leg 16} \\
\hline 155 & $06^{\circ} 07.38^{\prime} \mathrm{N}$ & $81^{\circ} 02.62 \mathrm{~W}$ & 2752 & $\begin{array}{l}\text { Lower Miocene/ } \\
\text { Middle Miocene }^{\text {a }}\end{array}$ \\
\hline 158 & $06^{\circ} 37.36^{\prime} \mathrm{N}$ & $85^{\circ} 14.16^{\prime} \mathrm{W}$ & 1953 & Middle Miocene ${ }^{a}$ \\
\hline Esso Petrel No. I & $13^{\circ} 40.00^{\prime} \mathrm{N}$ & $90^{\circ} 50.00^{\prime} \mathrm{W}$ & 586 & Upper Cretaceous \\
\hline
\end{tabular}

a Basalt basement penetrated.

datum was observed at Sites 494 through 497, but not in Sites 498 through 500 .

Three events occurring during the Brunhes paleomagnetic epoch were not observed at Leg 67 sites: the extinction of Globoquadrina pseudofoliata at 220,000 yr. ago, the extinction of Globorotalia tosaensis at about $590,000 \mathrm{yr}$. ago, and the appearance of Globoquadrina conglomerata at about $610,000 \mathrm{yr}$. ago. Pliocene occurrences of $G$. pseudofoliata were noted in some Leg 67 sites, but it was apparently excluded from the eastern Pacific during the Pleistocene (Thompson, 1976).

Many workers have found the intraspecific coiling directions of Pulleniatina useful as a continuous biostratigraphic tool (Kaneps, 1973; Saito, 1976; Thompson and Sciarrillo, 1978; Keigwin, 1978; Jenkins and Orr, 1980). The group coils dextrally throughout the Brunhes and Gauss paleomagnetic epochs, and is largely sinistral in the Matuyama and Gilbert. I found it useful at Leg 67 sites despite wide sampling intervals: general patterns of coiling noted in the Pacific can be recognized, particularly the strong sinistral trend near the Pliocene/Pleistocene boundary (see Figs. 3, 4, 8, 9, and 10).

Of the many planktonic foraminiferal species used to delineate the Pliocene/Pleistocene boundary, at Leg 67 sites this boundary is characterized by the extinctions of Globigerinoides fistulosus and $G$. obliquus at or slightly above the boundary (Thompson and Sciarrillo, 1978) and the appearance of Neogloboquadrina eggeri below it (Thompson and Sciarrillo, 1978). The ancestral form of $N$. eggeri, $N$. humerosa, coexists with $N$. eggeri in the lower Pleistocene until its extinction about $1 \mathrm{Ma}$ (Thompson and Sciarrillo, 1978). The first appearance of Globorotalia truncatulinoides was not observed, and, in fact, no G. truncatulinoides was encountered at these sites.

\section{Pliocene}

Relatively few planktonic foraminiferal events characterize the Pliocene at Leg 67 sites. The extinctions of limbate Globorotalia species, Globoquadrina altispira
(2.8 Ma) and Sphaeroidinellopsis spp. (3.0 Ma) (Berggren, 1973) mark the middle of the epoch. Poorly resolved extinctions of Globoquadrina venezuelana, Globorotalia acostaensis, Globigerina apertura, and $G$. nepenthes occur in the lower Pliocene but cannot be used for satisfactory correlation. A major shift in coiling directions of Globorotalia menardii from dextral to sinistral occurs in the lower Pliocene. The continuous evolution of Globorotalia tumida from G. plesiotumida, used by Jenkins and Orr (1972) to delineate the Miocene/Pliocene boundary, was not observed; the earliest occurrences of G. tumida at Leg 67 sites are not considered to represent this evolutionary change, but rather the first biogeographic entrance into the area.

\section{Miocene}

The middle and upper Miocene is poorly represented by planktonic foraminiferal faunas at Leg 67 sites. The abundance of siliceous microfossils along with low relative frequencies of thick-shelled foraminifers and agglutinated benthic taxa, or total barren intervals, point to these periods as times of intense carbonate dissolution and reduced sedimentation (van Andel et al., 1975). Many of the Leg 67 sections have an abyssal clay layer spanning the middle to upper Miocene, which may represent the time when the Cocos Plate was passing beneath the low fertility region presently located between the nutrient-rich waters of the tropical Pacific and the coastal upwelling zone. Typical planktonic foraminifers from the middle and upper Miocene at Leg 67 sites are Globigerinoides bulloideus, G. obliquus, Globorotalia acostaensis, and $G$. plesiotumida.

The lower part of the middle Miocene is represented by low relative abundances of the Globorotalia fohsi group and $G$. praemenardii. This fauna underlies the abyssal clay and provides a maximal age for initiation of the clay sedimentation.

The lower Miocene at Leg 67 sites is characterized by nannofossil chalk at Sites 495, 499, and 500, and by mudstone at Site 496. Typical lower Miocene taxa recovered from the chalk are Globigerina ciperoensis, Globigerinoides primordius, Globorotalia birnageae, $G$. kugleri, G. peripheroronda, G. siakensis, Catapsydrax dissimilis, Globigerinita stainforthi, and Globigerinatella insueta.

\section{Eocene}

Middle Eocene sediments were found only at Hole 494A. Although the age assignment of this unit is based on radiolarians (Westberg and Riedel, this volume), poorly preserved planktonic foraminifers were recovered including Chiloguembelina sp., Pseudohastigerina micra, Subbotina linaperta, Acarinina bullbrooki, and Morozovella spinulosa.

\section{Upper Cretaceous}

Upper Cretaceous (Maestrichtian) Globotruncana and Heterohelix were collected from the lowermost fossiliferous sediment at Hole 494A. Severe recrystallization prevented identification of many individuals. 


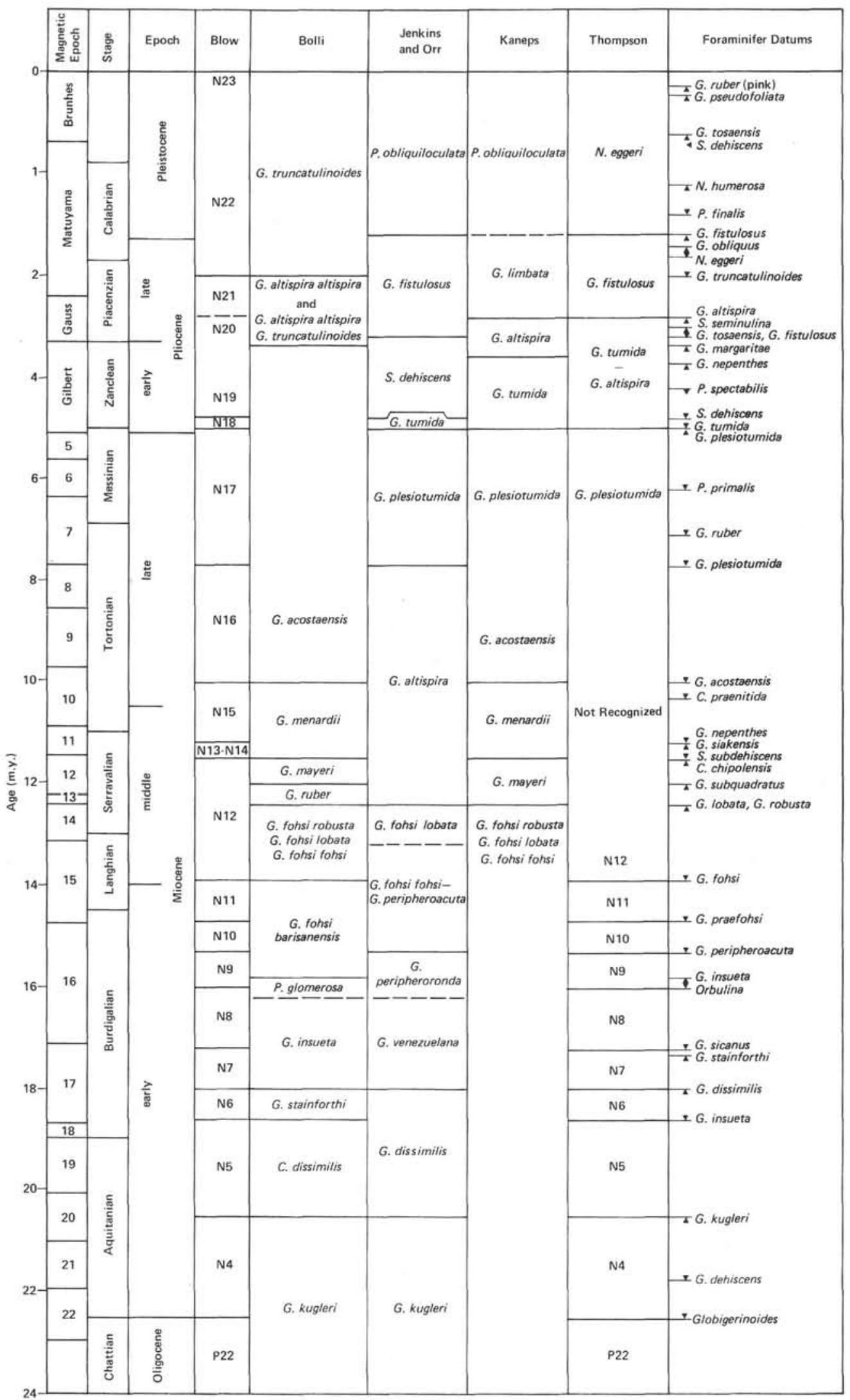

Figure 2. Biostratigraphic framework for Leg 67 planktonic foraminifers. (Correlations are made to the datum levels of Saito [1976] and Thompson and Sciarrillo [1978] relative to the paleomagnetic time scale of LaBrecque et al. [1977]. Middle and late Miocene zones were not recognized in Leg 67 samples.) 


\section{MIDDLE AMERICA TRENCH TRANSECT SITES: COCOS PLATE}

\section{Site 495}

Site 495 , the oceanic reference site, is on oceanic crust at an isolated ridge formed by a horst $22 \mathrm{~km}$ seaward from the Trench axis and at about 1925 meters above it at a water depth of 4140 meters. Magnetic anomalies at the site are known only from reconnaisance surveys and are thought to be Eocene (Heezen and Fornari, 1975).

Hole 495 (Fig. 3; Table 2, see back pocket) was continuously cored to 446.5 meters sub-bottom, and basalt was first encountered at $\mathbf{4 2 8 . 5}$ meters sub-bottom. Highly manganiferous and cherty chalk was found between 428.5 and 406 meters; the chalk continues up to 178 meters sub-bottom, but radiolarians were not seen below 351 meters, having been converted to chert. An abyssal brown clay that is barren of calcareous foraminifers exists between 171 and 178 meters sub-bottom. Hemipelagic olive to gray green diatomaceous mud was penetrated between 0 and 171 meters.

Foraminifer-rich nannofossil chalk rest conformably on the basalt in Core 46, Section 1, $112 \mathrm{~cm}$, with little apparent metamorphism of the carbonate. Benthic foraminifers are absent in the basal layers. The lowermost planktonic foraminiferal fauna is well-preserved and bears typical Oligocene to Miocene forms, including Globigerina angustiumbilicata, G. ciperoensis, G. sellii, Globigerinoides primordius, Globoquadrina dehiscens praedehiscens, G. venezuelana, Globigerinita stainforthi, Catapsydrax dissimilis, Globorotalia kugleri, G. na$n a$, and $G$. siakensis. The combination of G. kugleri, G. stainforthi, and Globigerinoides primordius permits assignment of the assemblage to Zone N4.

The interval between Cores 35 and 20 is characterized by increasing carbonate dissolution, indicated by lowered relative and absolute abundances of small and fragile taxa, increased fragmentation, increased abundance of benthic taxa, and larger quantities of siliceous microfossils. This dissolution has effectively destroyed many of the taxa commonly used for Miocene biostratigraphic zonations or severely reduced their vertical ranges.

The N5/N6 boundary, based on the first evolutionary appearance of Globigerinatella insueta, a fragile-test species, could be placed between Cores 28 and 29. However, the extinction of Catapsydrax dissimilis, a fairly resistant thick-walled species used by Blow (1969) to define his N6/N7 boundary, occurs no higher than Core 30 . Because of this dissolution effect, it has not been possible to place an N5/N6 boundary at this site.

Zones N8 and N9, based on the first evolutionary appearances of Globigerinoides sicanus and Orbulina suturalis, respectively, were drawn at Cores 27 and 25 . Both of these species are moderately resistant to dissolution, and the placement of zonal boundaries using these species must be regarded as provisional.

Zones N10 through N12 were based on portions of the evolutionary lineage of Globorotalia peripheroron$d a$ to Globorotalia fohsi (Blow and Banner, 1966). Zone $\mathrm{N} 10$ is marked by the evolution of $G$. peripheroacuta from $G$. peripheroronda, observed in Sample 495-22, CC. Zone N11, based on the development of keeled $G$. fohsi praefohsi from nonkeeled $G$. peripheroacuta, was placed between Sections 495-21-8 and 495-22-1. Zone N12, characterized by typical G. fohsi, was seen in Section 495-20-3 and 495-20-5. Dissolution has destroyed virtually all calcareous tests between this level and Core 17. The few Sphaeroidinellopsis present in samples from Core 20 did not resemble $S$. dehiscens subdehiscens sufficiently to delimit Zone N13.

Agglutinated benthic foraminifers, including Martinottiella, Cyclammina, Reophax, and Haplophragmoides, were found in very low abundances between Cores 19 to 16 . These samples were barren of planktonic foraminifers; occasional tests of planktonic taxa are probably contamination from caving of the hole. Core 17, however, contains a moderately well-preserved planktonic foraminiferal assemblage containing Globigerina bulloides, Globigerinoides bulloideus, G. obliquus, Globoquadrina altispira, Globorotalia acostaensis, and a deeply incised, limbate "mendardiiform" species similar to G. exilis (see Appendix). Crescenti (1966) identified Globigerinoides bulloideus from the Tortonian, and Jenkins and Orr (1972) reported Globorotalia exilis from the Messinian; given these criteria Core 17 can be established as upper Miocene.

The Miocene/Pliocene boundary, recognized here on the basis of the first evolutionary appearance of Globorotalia tumida from $G$. plesiotumida, was not observed at Site 495: the earliest G. tumida were seen in Sample 495-9-6, 23-25 cm, within the Globigerinoides fistulosus Zone, whereas the highest Globorotalia plesiotumida were in Sample 495-12-5, 40-42 cm. Lower Pliocene assemblages typically bear Globigerinoides obliquus, Globoquadrina altispira, G. venezuelana, Globorotalia acostaensis, and $G$. menardii. Low frequencies of dextrally coiled Pulleniatina first occur in Sample 495-12-7, $40-42 \mathrm{~cm}$.

The upper Pliocene was separated from the lower Pliocene by the extinction of Globoquadrina altispira and Sphaeroidinellopsis seminulina. Dissolution is fairly intense at this level, and Globigerinoides obliquus and ranges no higher. Jenkins and Orr (1972) showed $G$. fistulosus first appearing immediately following the extinction of Sphaeroidinellopsis, although Saito (1976) reported $G$. fistulosus as beginning $3.2 \mathrm{Ma}$, thus preceding the extinction. Globigerinoides fistulosus first appears in Sample 495-9-5, 65-67 cm, whereas Globoquadrina altispira and Sphaerodinellopsis disappear in Sample 495-10-2, 75-77 cm without apparent overlap. Upper Pliocene faunas include Neogloboquadrina humerosa, Globigerinoides fistulosus, Sphaeroidinella dehiscens, rare Globorotalia pertenuis, G. tumida, and Globoquadrina pseudofoliata. The coiling of Pulleniatina alternates between sinistral and dextral, but the wide sampling interval did not permit much resolution.

The Pliocene/Pleistocene boundary is approximated by the extinction of Globigerinoides fistulosus in the absence of $G$. truncatulinoides, G. obliquus, or other foraminiferal markers. The highest occurrence of G. fistulosus is in Sample 495-5-4, 90-92 cm, where it overlaps 


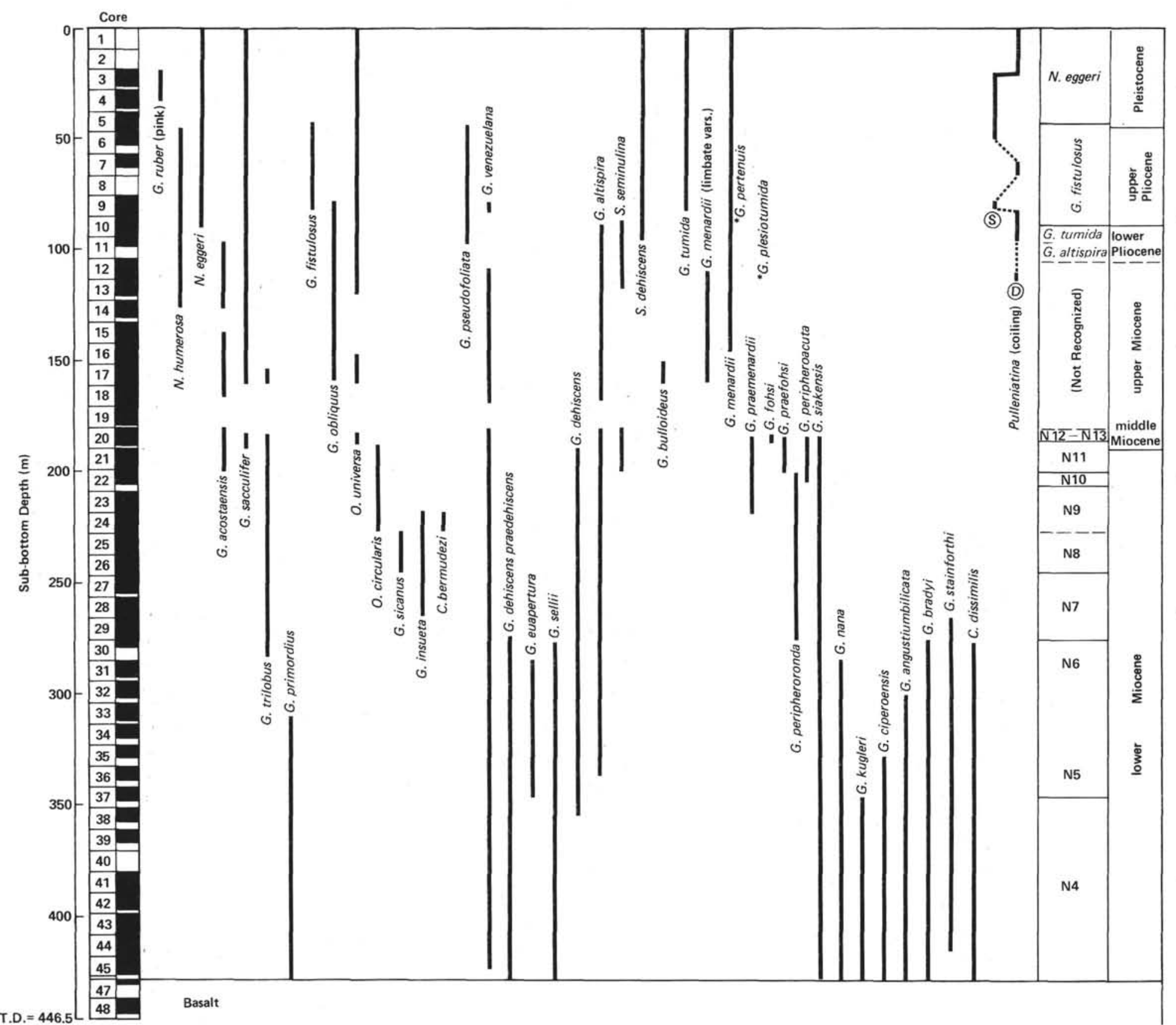

Figure 3. Range chart of planktonic foraminifers at Site 495. ( $\mathrm{D}=$ dextral, $\mathrm{S}=$ sinistral coiling direction. Asterisks indicate the position of an isolated occurrence at the site.) 
with Neogloboquadrina eggeri. Neogloboquadrina humerosa became extinct in the middle of the Pleistocene about 1.0 Ma (Thompson and Sciarrillo, 1978); this level occurs in Sample 495-5-4, 90-92 cm. Pink-pigmented $G$. ruber occurs between Samples 495-4-4, 40-42 $\mathrm{cm}$ and 495-3-1, 0-2 cm; Thompson et al. (1979) have noted that the typical range of pink-pigmented tests in the Indo-Pacific was between 250,000 and $120,000 \mathrm{yr}$. ago, although the lower limit is quite variable because of decomposition of the pigment. Coiling of Pulleniatina is dominantly sinistral below Section 495-3-3 and dextral above it, typical of coiling near the Matuyama/Brunhes boundary (Saito, 1976).

\section{Site 499}

Site 499 is located in the Middle America Trench off Guatemala about $1 \mathrm{~km}$ from the Trench's seaward wall and at a water depth of about 6125 meters. Single and multichannel records made during site surveying indicated an upper horizontal reflective sequence underlain by a landward-dipping sequence. Site 499 was located to sample both of these units, but not where they were thickest. In this manner, we hoped to date the trench fill, compare the calcareous basal sediments to the oceanic reference site, and examine the basalt basement in the immediate vicinity of the subduction zone.

Hole 499 (Fig. 4; Table 3) was drilled to a sub-bottom depth of 229.0 meters, just reaching the chalk; Hole 499A was offset slightly to examine the lateral facies variation of the trench fill and drilled to a sub-bottom depth of 43.0 meters; Hole 499B was washed to 201 meters sub-bottom and then cored into the basalt to 286.5 meters sub-bottom; Hole $499 \mathrm{C}$ was of fset along strike and washed to 260.0 meters with only one core of loose basalt rubble recovered. Hole 499D was washed to 216 meters sub-bottom depth, and one core of chalk and rock was recovered. Lithostratigraphy at Site 499 is similar to that found at Site 495 for the Miocene, but is quite different in the Quaternary where Site 495 has hemipelagic mud and Site 499 has turbidites. Both sites have a carbonate-free abyssal clay in the upper Miocene to lower Pliocene.

Foraminifer-rich nannofossil chalk was found in contact with basalt in Sample 499B-9,CC (23-25 cm). This lowermost planktonic foraminiferal fauna is not wellpreserved as the basal assemblage at Site 495: carbonate dissolution is evident from the large quantity of fragments, lower species diversity, and absence of fragile taxa. Age diagnostic taxa in the fauna include Globigerina euapertura, G. sellii, G. angustiumbilicata, Globigerinita stainforthi, Catapsydrax dissimilis, Globorotalia kugleri, G. nana, G. siakensis, Globoquadrina dehiscens praedehiscens, and $G$. venezuelana. Species found at Site 495 but missing from this assemblage were $\mathrm{Globi-}$ gerina ciperoensis and Cassigerinella chipolensis.

Globigerinoides primordius was not found until Sample 499B-8-2, 47-49 cm; I cannot be certain that its first occurrence at this depth is evolutionary, hence defining the N3/N4 boundary, but the generally poor preservation leads me to conclude at this time that the basal assemblage is within the lower Miocene in Zone N4.
Further, poor preservation of planktonic foraminifers continues throughout the tan colored chalk at the bottom of the hole and does not improve until the bluish gray colored chalk is encountered at the top of Core 8 in Hole 499B.

The N4/N5 boundary was placed in the middle of Core 7 (499B), because Globorotalia kugleri was present in the topmost sample examined from Sample 499B-8-1, $52-54 \mathrm{~cm}$, but was absent from Sample 499B-6-1, 78-80 $\mathrm{cm}$ (no sediment was recovered from Core 7). The first occurrence of Globigerinatella insueta in Sample 499B$3-3,33-35 \mathrm{~cm}$ is in conflict with the range of $C$. dissimilis up to Sample 499B-4-1, 53-55 cm, as it was in Hole 495. Again, no N5/N6 boundary was drawn. Catapsydrax dissimilis, a more resistant species, is believed to lie closer to its true level of extinction despite dissolution, and the N6/N7 boundary was placed between Cores 3 and 4 (Hole 499B).

The N7/N8 boundary, drawn from the first occurrence of Globigerinoides sicanus, was located in Sample 499B-25-3, 53-55 cm but not observed in Hole 499B. The N8/N9 boundary, based on the first Orbulina suturalis, occurred in Sample 499-25-3, 53-55 cm (223.5 m sub-bottom) and in Core 3, Section 1, top, in Hole 499B (220 m sub-bottom). The N9/N10 boundary, based on the evolutionary appearance of Globorotalia peripheroacuta, was seen in Samples 499-24-1, 20-22 cm (210 m sub-bottom) as well as 499B-1,CC (14-16 cm) (201 m sub-bottom). The apparent discrepancy between the biostratigraphic zonal assignments at the top of Hole 499B and the bottom of Hole 499 appears to be one of relative sub-bottom depths and the DSDP convention of labelling core sections from the physical position of the retrieved sediment in the barrel. A narrow, highly dissolved carbonate interval with abundant volcanic ash occurs in Sample 499-24,CC (214.5 m sub-bottom) and in the bottom of Section 499B-3-1 (221 m sub-bottom); if these two layers are coeval, much of the stratigraphic offset converges.

A major carbonate-free interval spanning the middle Miocene to upper Pliocene lies between Samples 49923-1, 73-75 $\mathrm{cm}$ and 499-23-1, 93-95 $\mathrm{cm}$. The topmost carbonate unit lies within the interval of Zone N10, not reaching the first appearance of $G$. fohsi praefohsi. Agglutinated benthic foraminifers including Martinottiella and Cyclammina are the only forms present in the carbonate barren interval.

Core 22, Hole 499, was placed in the upper Pliocene, above the extinctions of Globoquadrina altispira and Sphaeroidinellopsis. The Pliocene/Pleistocene boundary between Cores 21 and 22 was located with nannofossils in the absence of Globigerinoides fistulosus and $G$. obliquus. The contact between the G. fistulosus and Neogloboquadrina eggeri zones was located between Cores 17 and 15. Pleistocene foraminiferal assemblages in Hole 499 are neither well-preserved nor diverse. $N$. humerosa persists upwards to the top of Core 15. The coiling of Pulleniatina, not considered to be very helpful at this site because of the few specimens encountered, is dominantly sinistral in the lower early Pleistocene and dextral in the top 60 meters of the hole. Pink-pigmented 


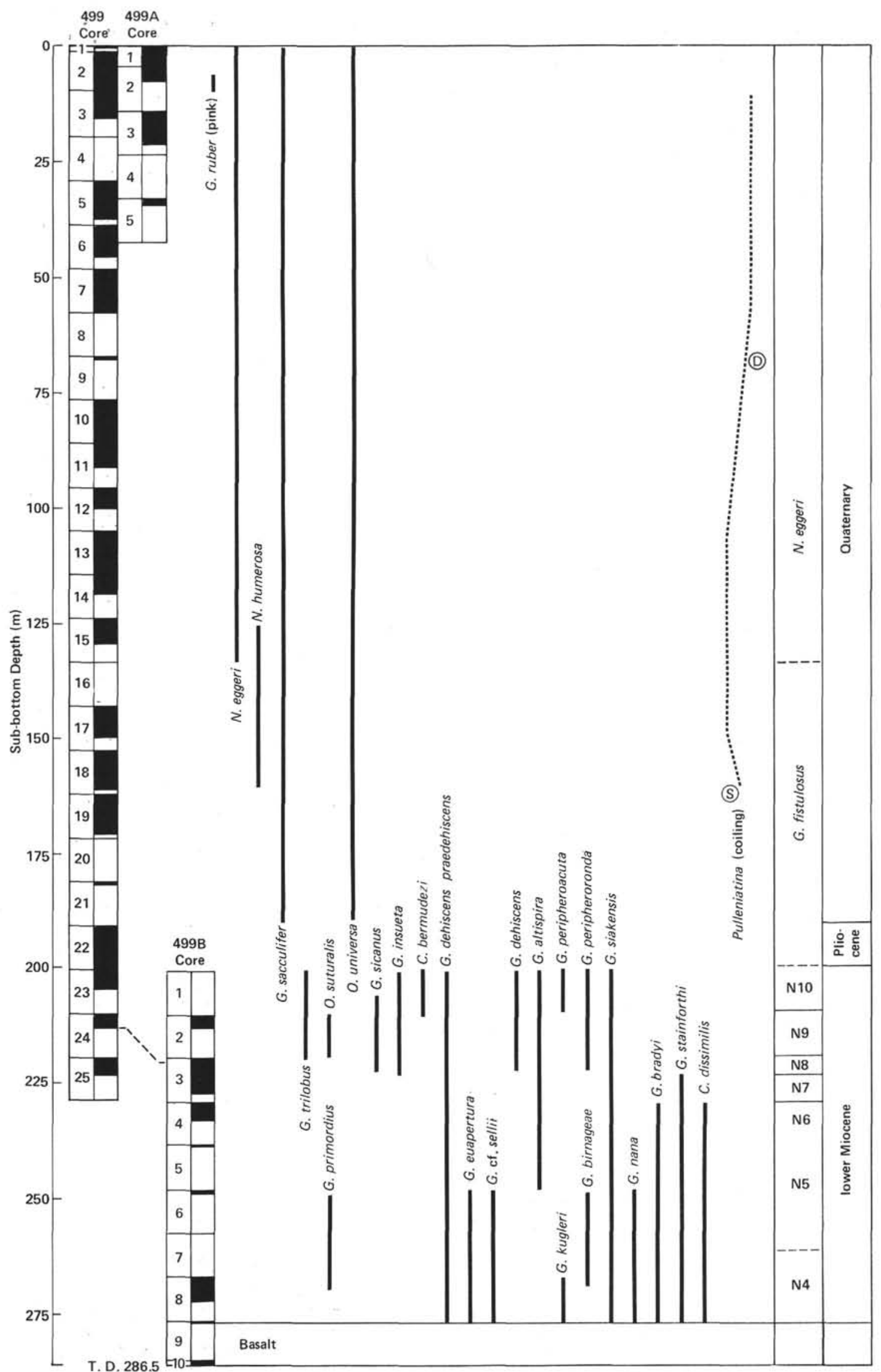

Figure 4. Range chart of planktonic foraminifers at Site 499. ( $\mathrm{D}=$ dextral, $\mathrm{S}=$ sinistral coiling direction.) 
Globigerinoides ruber occurs between Samples 4992 ,CC (10-12 cm) and 499-2-4, 60-62 cm; it was not seen in Hole 499A.

Clasts or reworked sediments are common in the turbidites at Site 499; typically they are olive or gray in color. They olive colored clasts from Hole 499A bear stained Globorotalia menardii, Globigerinoides ruber, G. cf. fistulosus, Globigerina bulloides, Orbulina, Pyrgo, and Oridorsalis, unstained Globigerinoides ruber, Eggerella, Pyrgo, Uvigerina senticosa, and Cibicides along with volcanic ash and radiolarians. The gray clasts contain abundant volcanic ash and radiolarians, and unstained Eggerella, Martinottiella, Globobulimina, and a rare Globorotalia siakensis.

Benthic foraminifers from the late Quaternary turbidites of Hole 499, Cores 1 through 3, and Hole 499A, Cores 1 through 5 , indicate progressively shallower sources through time to the present. Lower-bathyaldepth faunas occur below Core 12, including Pullenia, Uvigerina senticosa, and Melonis pompilioides. Upper bathyal assemblages were found between Cores 1 and 9 , Hole 499, including Angulogerina, Miliolina, Bolivina, and Spiroloculina. Shelf taxa were found in Cores 1 through 7, Hole 499, and 1 through 5, Hole 499A, including Elphidium, Cribroelphidium, Textularia, Ammonia, and ostracodes.

\section{Site $\mathbf{5 0 0}$}

Site 500 is located at the juncture of the Trench and the base of the landward wall, at a water depth of 6100 meters. Seismic records indicated that the Trench sequence of horizontal reflectors overlying landward-dipping reflections became obscured by faults in the vicinity of the landward wall. A prime goal of drilling in this location was to investigate the Trench sediments as they pass into the subduction zone for any deformation or lithologic changes. Three holes were drilled (Fig. 5; Table 4), each terminating in basalt at unexpectedly shallow levels: Hole 500 at 161 meters sub-bottom; Hole 500A, 114 meters; Hole 500B, 125 meters. Hole 500 penetrated lower Miocene chalk in contact with basalt in a sequence similar to that at Site 499; Holes 500A and $500 \mathrm{~B}$ penetrated only turbidites resting on rubbly basalt, possibly not true basement.

Coarse fractions from the turbidites (Hole 500, Cores 1 to 10 , Section 1; Hole 500A, Cores 1 to 2 ; Hole 500B, Cores 1 to 2 ) contain planktonic foraminifers (moderately well-preserved, but not abundant), benthic foraminifers (well-preserved and often abundant), radiolarians, plant fragments (carbonized), fecal pellets, fish bones, fish scales, fish teeth, otoliths, echinoid spines, mollusc fragments, ostracodes, and large amounts of gravel, sand, and volcanic ash. This site had the most shallow-water indicators of any Leg 67 sites including the slope sites. Typical Neogloboquadrina eggeri Zone planktonic foraminiferal species include Globigerinita glutinata, Globigerinoides ruber (no pink-pigmented forms), G. sacculifer, Globorotalia menardii, and $N$. eggeri; the lack of pink Globigerinoides ruber indicates that this assemblage may be younger than $120,000 \mathrm{yr}$.the age of the extinction level of the taxon. Benthic fora- minifers indicate derivation from many sources: middle or lower bathyal taxa were Globobulimina pacifica, Melonis salisburyi, Uvigerina peregrina, Martinottiella; upper bathyal taxa were Angulogerina, Bolivinia pacifica, B. spissa, B. pseudobeyrichi, Valvulinerina; and shelf taxa were Ammonia, Elphidium, and Nonionella basispinata.

The top of the chalk in Sample 500-10-2, 80-82 cm was identified as lower Miocene Zone N8 on the basis of a well-preserved planktonic foraminiferal assemblage containing abundant Globoquadrina altispira, G. dehiscens, Globigerinoides trilobus, Globorotalia siakensis, and Clavatorella bermudezi; no Globigerinatella insueta or Globorotalia peripheroacuta were observed. A tentative N7/N8 boundary was drawn, because the earliest occurrence of Orbulina suturalis coincides with that of the earliest G. sicanus in Sample 500-11-4, 37-40 cm; instead, the N6/N7 boundary was drawn at this level. As at Sites 495 and 499, the earliest occurrence of Globigerinatella insueta has been obliterated by dissolution to a level above the Catapsydrax dissimilis extinction in Sample 500-12-3, 124-126 cm. Thus no N5/N6 boundary was made (Fig. 6). The extinction of Globorotalia kugleri in Sample 500-14-1, 28-30 cm delineates the N4/N5 boundary. The occurrence of Globigerinoides primordius at the bottom of this hole in Sample 500-17, CC (15-17 cm), immediately above the contact with basalt, indicates that the basalt sediments are in the lower Miocene Zone N4. Species common at this level include G. primordius, Globigerina euapertura, G. angustiumbilicata, Globorotalia siakensis, G. kugleri, G. nana, and $C$. dissimilis.

\section{LOWER SLOPE: SITES 494 AND 498}

\section{Site 494}

Site 494, located on the lower continental slope about $3 \mathrm{~km}$ from the Trench axis and 580 meters above it, is situated on a small terrace about $2 \mathrm{~km}$ wide and $18 \mathrm{~km}$ long. A major drilling objective at this site was to determine if the terrace and several above and below it are related to imbricate thrusting or due to slumping of small blocks.

Five dissimilar lithologies were recovered from the two holes drilled (Fig. 7; Table 5, back pocket) before the site was terminated because of poor recovery. The subducting Cocos Plate was not penetrated. The topmost 186 meters sub-bottom are Holocene to Miocene diatomaceous mud; the next $\mathbf{2 5}$ meters are lower Miocene to upper Oligocene hemipelagic clay; the third unit, 47 meters of middle Eocene volcanic mudstone; the final fossiliferous unit, 19 meters of Maestrichtian calcareous mudstone; and the lowermost unit, 1 meter (total recovery) of altered mafic to intermediate igneous rocks and gravel. Microfossils are absent or found only in very low frequencies, probably because the site was always below or near the CCD.

Hole 494, Cores 1 to 4, and Hole 494A, Cores 1 to 17, penetrated the late Quaternary Neogloboquadrina eggeri Zone. Foraminiferal abundances varied widely. Typical planktonic species included N. eggeri, N. blowi, 
Table 3. Planktonic foraminifers and other microconstituents of Site 499.

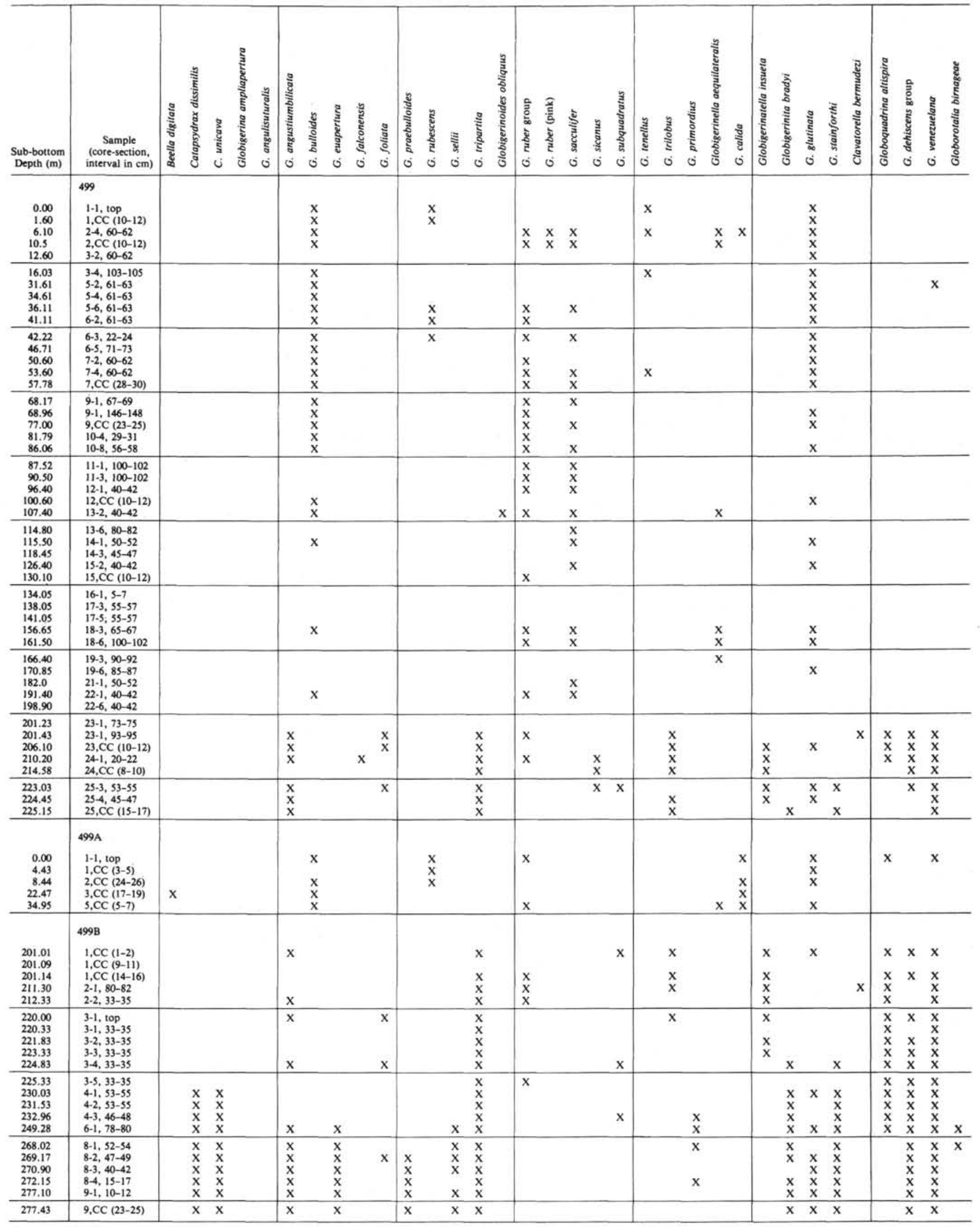

Note: See Table 2 for an explanation of the symbols and abbreviations used. 
Table 3. (Continued).

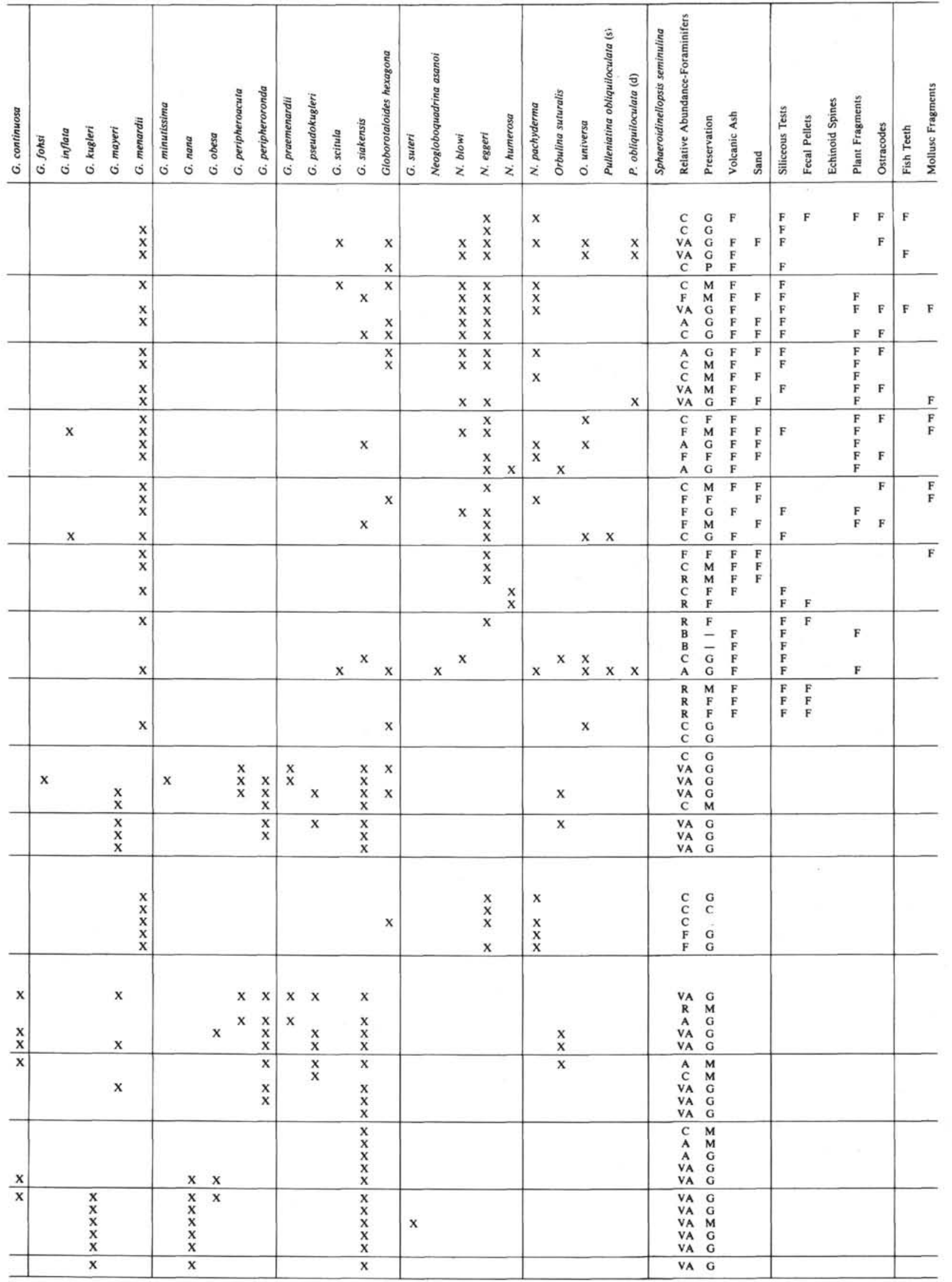




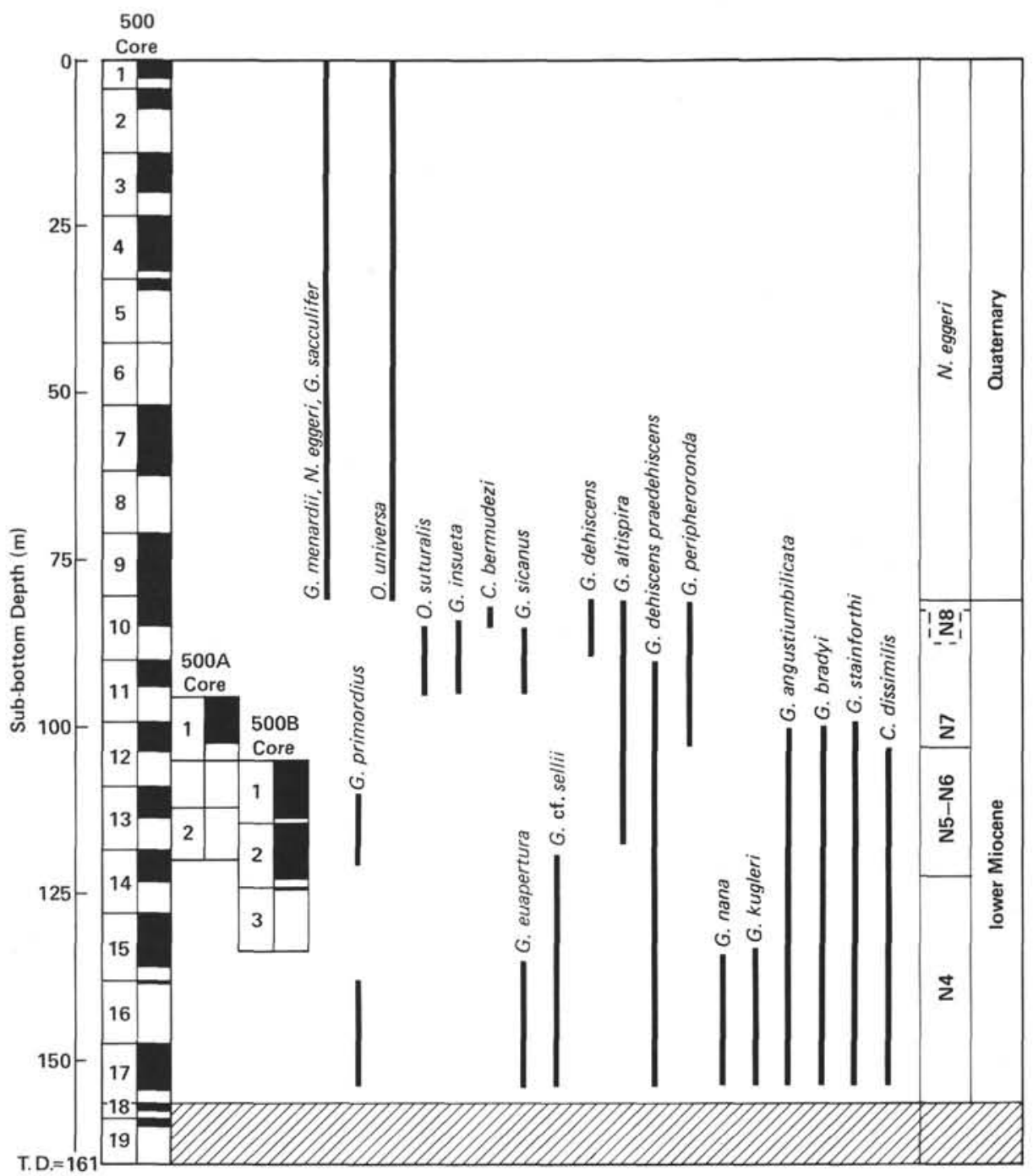

Figure 5. Range chart of planktonic foraminifers at Site 500.

Globorotalia menardii, Globigerinoides ruber, G. sacculifer, and Globigerinita glutinata; benthic taxa, including Bolivina, Bulimina, Uvigerina, Cassidulina, and Stainforthia, suggest initial deposition at middle or lower bathyal depths and subsequent sediment displacements to the present location below the CCD. Pink-pigmented Globigerinoides ruber was found in Sample 494$1-1,60-64 \mathrm{~cm}$, indicating that those sediments younger than $120,000 \mathrm{yr}$. were not recovered.

Nannofossils (Muzylov, this volume) were used to locate the Pliocene/Pleistocene boundary between Cores 16 and 17 (494A), although the highest occurrence of $G$. fistulosus was in Sample 494A-19-2, 56-60 cm. Poor preservation has destroyed upper Pliocene to lower Pleistocene foraminiferal faunas from the record. Globoquadrina altispira is common in Sample 494A-19-1, $56-60 \mathrm{~cm}$, showing that this level is no younger than the middle Pliocene; $G$. dehiscens and Globorotalia plesiotumida are rare in Samples 494A- 20-2, 80-85 cm to $494 \mathrm{~A}-20-4,80-85 \mathrm{~cm}$, indicating that upper Miocene sediments were drilled. Benthic foraminifers, including Bulimina, Uvigerina peregrina, U. senticosa, Angulo- gerina, Melonis pompilioides, Pullenia bulloides, and Bathysiphon, are typical of lower bathyal depths, but probably shallower than this site's current depth.

The lithologic contact at a sub-bottom depth of 185 meters between middle or upper Miocene sandy mudstones and lower Miocene claystones in Section 494A-4$1,70 \mathrm{~cm}$, is possibly correlative to the abyssal clay seen at other Leg 67 sites of this age. Planktonic foraminiferal species below this contact are lower Miocene or upper Oligocene: G. nana, Catapsydrax dissimilis, Globigerina ciperoensis, Globoquadrina venezuelana, Globoquadrina dehiscens praedehiscens and Globigerina sellii all span the Oligocene/Miocene boundary. These individuals are highly recrystallized and many have been flattened. Benthic foraminifers, including Lenticulina and Stilostomella, are rare in Cores 20, Section 4 through 22, Section 3 (Hole 494A).

Core 494A-23 to Sample 494A-27, CC have been assigned by nannofossils (Muzylov, this volume) and radiolarians (Westberg and Riedel, this volume) to the middle Eocene. Foraminifers found in Core 494A-27, Section 1, including Chiloguembelina, Pseudohastiger- 
ina micra, Acaranina bullbrooki, Morozovella spinulosa, and Subbotina linaperta, support this age assignment but do not refine it much. These individuals appear to be completely recrystallized and are not accompanied by benthic taxa. A small mass of middle Eocene sediment at the top of Core 494A-29 is believed to be the result of downhole caving.

Cores 494A-28 and 494A-30 were dated as Maestrichtian by abundant Abathomphalus mayaroensis, Raceguembelina, Planoglobulina, and Pseudotextularia in Core 28, and by Globotruncana arca, G. elevata, and $G$. fornicata in Cores 29 and 30. These assemblages are relatively diverse, although highly recrystallized, but the recovery of the interval is poor. Core 28 was placed in the A. mayorensis Zone and Cores 29 and 30 were placed in the Globotruncana gansseri Zone (see Premoli Silva and Bolli, 1973). Benthic foraminifers were not abundant, suggesting pelagic sedimentation conditions away from terrigenous areas; small planktonic taxa are abundant, suggesting minimal dissolution and deposition at depths near the lysocline.

\section{Site 498}

Site 498 is located $1.8 \mathrm{~km}$ southeast along strike from Site 494 at a water depth of 5478 meters. This site was placed in an area shown by seismic records to be less deformed than the Site 494 area, and it was hoped that the stratigraphic gaps that resulted from drilling at Site 494 would be resolved. Because the recovery at Site 494 had been good above 200 meters sub-bottom depth, Hole 498A was spot-cored at 50-meter intervals to 200 meters. Below the 200-meter depth, we hoped to recover the Miocene/Eocene contact, the Eocene/Cretaceous contact, Oligocene, Paleocene, and any rocks below the Maestrichtian not recovered at Site 494. Ice clathrates at 310 meters (Core 15, Hole 498A) prompted termination of drilling at the site before these goals could be accomplished.

Two stratigraphic units were recorded at Site 498 (Fig. 8; Table 6). The uppermost unit is Quaternary to Pliocene biogenic mud in Cores 1 to 2 (Hole 498), and Cores 1 to 4 (Hole 498A), (212 m sub-bottom). The second unit is Miocene mudstone that was different in lithology and also much thicker than the same-aged materials at Site 494.

The Quaternary muds spot-cored in the upper 200 meters contain planktonic foraminiferal species belonging to the Neogloboquadrina eggeri Zone, including Globigerinoides ruber, Globorotalia menardii, Globigerinoides sacculifer, Globigerinita glutinata, N. eggeri, $N$. pachyderma, and infrequent Pulleniatina. Benthic foraminiferal assemblages were similar to those at Site 494, with dominant Bolivina, Uvigerina, and Melonis.

The washed interval between 165 and 202 meters in Hole 498A was partially recovered, and, although not formally described in the Site 498 report, was examined aboard ship for its microfossils. The vertical position of this material in the hole, however, is uncertain. Planktonic foraminiferal species from the top of this material indicate Pliocene sediments, including Globigerinoides obliquus, dextral Pulleniatina, and Globoquadrina vene- zuelana. Lower Miocene planktonic foraminiferal taxa including Catapsydrax dissimilis, Globorotalia nana, Globigerinita stainforthi, and Globoquadrina dehiscens were collected from the bottom of the material. These assemblages are typical of the blue clasts common at Site 494 , but here were washed from unbrecciated sediment layers.

The sediments recovered from Hole 498A, Cores 5 through 15 , have poorly preserved foraminiferal assemblages with low frequencies of specimens. Most of the samples were dominated by benthic taxa including $U v i-$ gerina, Pyrgo, Stilostomella, Melonis pompilioides, Pullenia bulloides, and Globobulimina. Long-ranging planktonic taxa indicated a normal biostratigraphic progression: the Pliocene was indicated by $N$. humerosa, Globorotalia cf. exilis, and sinistral Pulleniatina; the upper Miocene had Globoquadrina venezuelana and Globorotalia plesiotumida; the middle Miocene to lower Miocene had G. peripheronda, G. siakensis, Globoquadrina altispira, and Globigerinoides trilobus. The basal sediment of Hole 498A, Core $15^{\circ}$, Section 1 is a coarse, wellsorted sand that is not lithified. Lower Miocene (N8) planktonic foraminifers present include G. trilobus, $G$. sicanus, Globorotalia siakensis, G. birnageae, G. praescitula, Globigerinita stainforthi, and Globoquadrina dehiscens. Benthic foraminifers suggest displacement of a much shallower assemblage: deep-water forms such as Uvigerina, Melonis, Stilostomella, and Sphaeroidina bulloides are accompanied by Amphistegina, Lenticulina, and Anomalina. The lower Miocene recrystallization seen at Site 494 was absent at this site.

\section{SLOPE SITES: SITES 496 AND 497}

\section{Site 497}

Site 497 is situated on the continental slope at a water depth of 2350 meters; drilling was intended to penetrate the sedimentary cover to a landward-dipping reflector having igneous rock seismic velocities. The goal was not achieved, because when clathrates were encountered near a sub-bottom depth of 400 meters, drilling was terminated while still in Pliocene sediments.

Two rock units were recovered at this site (Fig. 9; Table 7): Quaternary mud (Cores 1-16, $149.5 \mathrm{~m}$ subbottom depth) underlain by Pliocene sandy mudstone (Cores 17-24, 149.5-295.5 m sub-bottom depth). These two units are basically continuous depositional records, differing mainly in the higher sand content toward the bottom and greater induration. Abundant foraminifers, diatoms, radiolarians, and nannofossils occur throughout the hole; fecal pellets were seen down to Core 19; ostracodes were occasionally found down to Core 10 .

Planktonic foraminiferal markers for the Pliocene/ Pleistocene boundary do not agree well with the level (between Cores 17 and 18) delineated by radiolarians and nannofossils. The earliest occurrence of Neogloboquadrina eggeri was in Sample 497-14-3, 108-110 cm, whereas the highest occurrence of Globigerinoides fistulosus was in Sample 497-23-3, 30-32 cm. The middle of the Pliocene was equally difficult to identify despite abundant planktonic foraminifers: the highest occur- 
Table 4. Planktonic foraminifers and other microconstituents from Hole 500.

\begin{tabular}{|c|c|c|c|c|c|c|c|c|c|c|c|c|c|c|c|c|c|c|c|c|c|c|}
\hline $\begin{array}{l}\text { Sub-bottom } \\
\text { Depth } \\
\text { (m) }\end{array}$ & $\begin{array}{c}\text { Sample } \\
\text { (core-section, } \\
\text { interval in } \mathrm{cm} \text { ) }\end{array}$ & 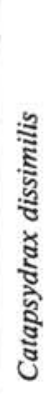 & 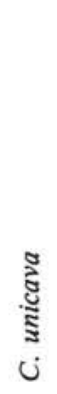 & 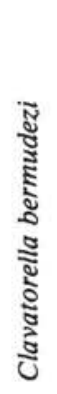 & 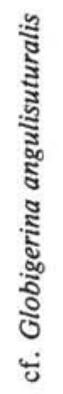 & 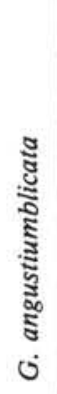 & 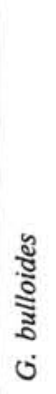 & 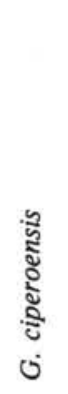 & 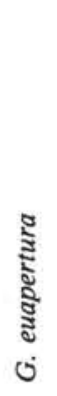 & $\underbrace{\stackrel{5}{0}}_{0}$ & 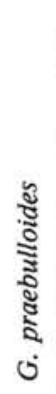 & 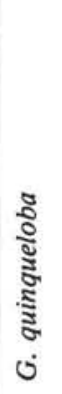 & 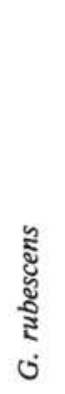 & 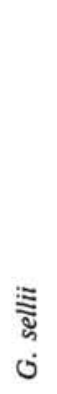 & 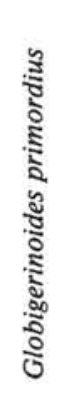 & 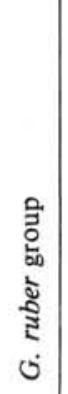 & 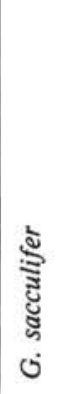 & 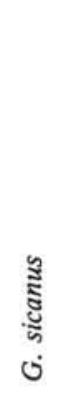 & 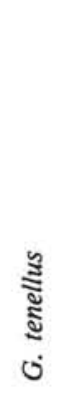 & $\begin{array}{l}\stackrel{y}{0} \\
\stackrel{0}{\Xi} \\
0 \\
0\end{array}$ & 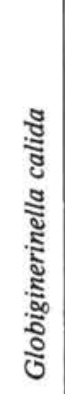 & 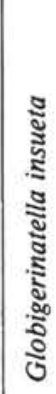 \\
\hline $\begin{array}{r}0.00 \\
3.07 \\
6.17 \\
20.58 \\
32.38\end{array}$ & $\begin{array}{l}1-1, \text { top } \\
1-3,7-9 \\
2-2,17-19 \\
3-5,58-60 \\
4-6,138-140\end{array}$ & & & & & & $\begin{array}{l}\mathrm{X} \\
\mathrm{X} \\
\mathrm{X} \\
\mathrm{X} \\
\mathrm{X}\end{array}$ & & & & & & $X$ & & & $\begin{array}{l}\mathrm{X} \\
\mathrm{X} \\
\mathrm{X} \\
\mathrm{X}\end{array}$ & $\begin{array}{l}\mathrm{X} \\
\mathrm{X} \\
\mathrm{X} \\
\mathrm{X} \\
\mathrm{X}\end{array}$ & & $\begin{array}{l}\mathrm{X} \\
\mathrm{X}\end{array}$ & & $\begin{array}{l}\mathrm{X} \\
\mathrm{X}\end{array}$ & \\
\hline $\begin{array}{l}34.78 \\
61.30 \\
64.17 \\
76.27 \\
80.35\end{array}$ & $\begin{array}{l}5-2,28-30 \\
7-8,30-33 \\
8-2,117-119 \\
9-4,77-79 \\
9-9,15-17\end{array}$ & & & & & & $\begin{array}{l}\mathrm{X} \\
\mathrm{X} \\
\mathrm{X} \\
\mathrm{X} \\
\mathrm{X}\end{array}$ & & & & & $x$ & $x$ & & & $\begin{array}{l}\mathrm{X} \\
\mathrm{X} \\
\mathrm{X}\end{array}$ & $\begin{array}{l}X \\
X\end{array}$ & & $\mathrm{X}$ & & & \\
\hline $\begin{array}{l}81.40 \\
82.80 \\
84.30 \\
85.70 \\
91.87\end{array}$ & $\begin{array}{l}10-1,90-92 \\
10-2,80-82 \\
10-3,80-82 \\
10, C C(20-22) \\
11-4,37-40\end{array}$ & & $\mathrm{X}$ & $\begin{array}{l}X \\
X\end{array}$ & & & $\mathrm{X}$ & & & & & & & & & $\begin{array}{l}\mathrm{X} \\
\mathrm{X} \\
\mathrm{X} \\
\mathrm{X}\end{array}$ & $\begin{array}{l}\mathrm{X} \\
\mathrm{X} \\
\mathrm{X} \\
\mathrm{X} \\
\mathrm{X}\end{array}$ & $\begin{array}{l}X \\
X\end{array}$ & & & & $\begin{array}{l}\mathrm{X} \\
\mathrm{X} \\
\mathrm{X}\end{array}$ \\
\hline $\begin{array}{l}100.10 \\
101.60 \\
103.74 \\
111.64 \\
118.78\end{array}$ & $\begin{array}{l}12-1,60-62 \\
12-2,60-62 \\
12-3,124-126 \\
13-2,114-116 \\
14-1,28-30\end{array}$ & $\begin{array}{l}X \\
X \\
X\end{array}$ & & & & $\begin{array}{l}\mathrm{X} \\
\mathrm{X} \\
\mathrm{X} \\
\mathrm{X} \\
\mathrm{X}\end{array}$ & $\begin{array}{l}\mathrm{X} \\
\mathrm{X}\end{array}$ & & & & & & & $X$ & $\mathrm{X}$ & $\begin{array}{l}\mathrm{X} \\
\mathrm{X} \\
\mathrm{X} \\
\mathrm{X} \\
\mathrm{X}\end{array}$ & $\begin{array}{l}\mathrm{X} \\
\mathrm{X} \\
\mathrm{X}\end{array}$ & & & $\begin{array}{l}X \\
X\end{array}$ & & \\
\hline $\begin{array}{l}123.28 \\
128.50 \\
131.50 \\
134.50 \\
137.78\end{array}$ & $\begin{array}{l}14-4,28-30 \\
15-1,50-52 \\
15-3,50-53 \\
15-5,50-53 \\
16-1,28-30\end{array}$ & $\begin{array}{l}\mathrm{X} \\
\mathrm{X} \\
\mathrm{X} \\
\mathrm{X} \\
\mathrm{X}\end{array}$ & & & $\mathrm{X}$ & $\begin{array}{l}\mathrm{X} \\
\mathrm{X} \\
\mathrm{X} \\
\mathrm{X} \\
\mathrm{X}\end{array}$ & & $\begin{array}{l}X \\
X\end{array}$ & $\begin{array}{l}\mathrm{X} \\
\mathrm{X} \\
\mathrm{X}\end{array}$ & & & & & $\begin{array}{l}X \\
X \\
X \\
X \\
X\end{array}$ & $\begin{array}{l}\mathrm{X} \\
\mathrm{X} \\
\mathrm{X} \\
\mathrm{X}\end{array}$ & & & & & & & \\
\hline $\begin{array}{l}147.20 \\
148.70 \\
154.15\end{array}$ & $\begin{array}{l}17-1,20-22 \\
17-2,20-22 \\
17, \mathrm{CC}(15-17)\end{array}$ & $\begin{array}{l}\mathrm{X} \\
\mathrm{X} \\
\mathrm{X}\end{array}$ & & & & $\begin{array}{l}\mathrm{X} \\
\mathrm{X} \\
\mathrm{X}\end{array}$ & & & $\begin{array}{l}\mathrm{X} \\
\mathrm{X} \\
\mathrm{X}\end{array}$ & $x$ & $\mathrm{X}$ & & & $\begin{array}{l}\mathrm{X} \\
\mathrm{X} \\
\mathrm{X}\end{array}$ & $\begin{array}{l}X \\
X \\
X\end{array}$ & & & & & & & \\
\hline
\end{tabular}

Note: See Table 2 for an explanation of the symbols and abbreviations used.

rence of Sphaerodinellopsis was in Sample 497-25-4, $56-58 \mathrm{~cm}$, immediately below the barren Sample 497-251, $56-58 \mathrm{~cm}$; the highest occurrence of Globoquadrina altispira was in Sample 497-28-2, 51-53 cm. Thus although these two extinctions are very close in time, they are widely separated at this site, and in intervals accompanied by many barren samples. This section may represent a very expanded middle Pliocene sequence, but one characterized by intense dissolution.

The earliest occurrence of Globorotalia tumida in Section 497-35-6, 61-63 cm may be used to locate the Miocene/Pliocene boundary. Its ancestral form, G. plesiotumida is common at this site, but transitional $G$. tumida was not found close to the boundary as at other Leg 67 sites, suggesting an ecological first occurrence rather than an evolutionary one. Other upper Miocene to lower Pliocene taxa at the bottom of this site are Globoquadrina venezuelana, Globigerina bulloides, and Globorotalia praemiocenica.
Benthic foraminifers are typical of lower to middle bathyal depths, probably little displaced from the source. Dominant taxa include Hoeglundina elegans, Globobulimina, Bulimina barbata, B. pagoda, Uvigerina peregrina, U. senticosa, U. hispida, Pyrgo, Sphaeroidina bulloides, Pullenia bulloides, Nodosaria, Stilostomella, Martinottiella, Eggerella, and Melonis. Near the bottom of the hole, below Core 34, the assemblage has the additional taxa Frondicularia, Goesella, Latacarinina.

\section{Site 496}

Site 496 is the shallowest of the Leg 67 sites, placed on the upper part of the Trench slope in 2050 meters water. Seismic records showed two reflectors, one dipping toward the Trench, which turned out to be the base of the hemipelagic cover, and a second dipping landward possibly continuous with deeper layers described by Seely (1979). The site was terminated approximately 
Table 4. (Continued).

\begin{tabular}{|c|c|c|c|c|c|c|c|c|c|c|c|c|c|c|c|c|c|c|c|c|c|c|c|c|c|c|c|}
\hline 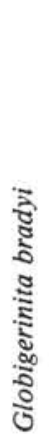 & 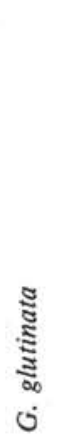 & 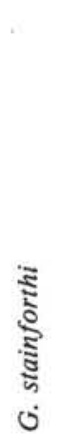 & 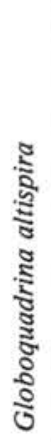 & 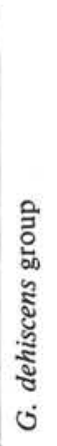 & 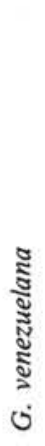 & 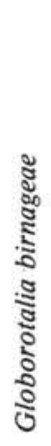 & 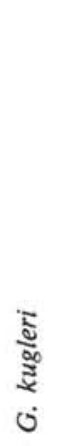 & 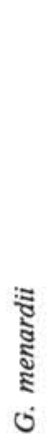 & $\begin{array}{c}\stackrel{\Xi}{5} \\
\dot{\Xi} \\
\dot{0}\end{array}$ & 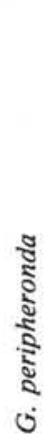 & 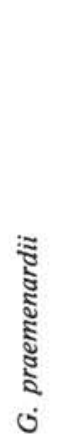 & 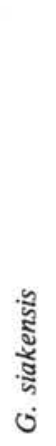 & 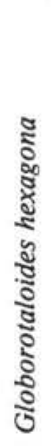 & 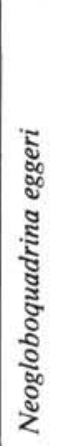 & 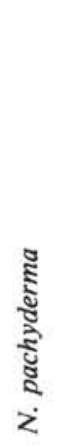 & 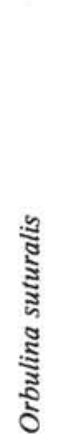 & 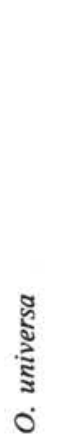 & 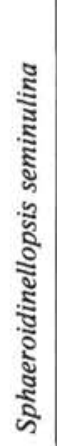 & 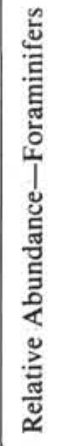 & 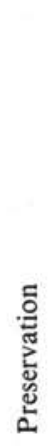 & $\begin{array}{l}\frac{5}{2} \\
\frac{0}{3} \\
\frac{0}{0} \\
>\end{array}$ & 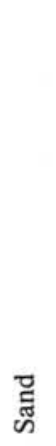 & 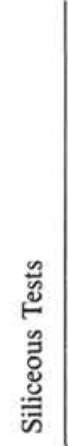 & 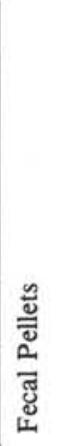 & 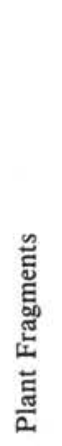 & 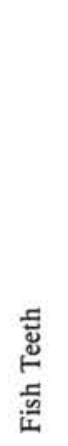 & 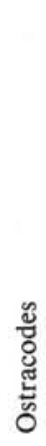 \\
\hline & $\begin{array}{l}\mathrm{X} \\
\mathrm{X} \\
\mathrm{X} \\
\mathrm{X} \\
\mathrm{X}\end{array}$ & & & & $X$ & & & $\begin{array}{l}X \\
X \\
X \\
X \\
X\end{array}$ & & & & & $x$ & $\begin{array}{l}\mathrm{X} \\
\mathrm{X} \\
\mathrm{X} \\
\mathrm{X} \\
\mathrm{X}\end{array}$ & & & $\begin{array}{l}X \\
X \\
X\end{array}$ & & $\begin{array}{l}\text { A } \\
\text { A } \\
\text { C } \\
\text { A } \\
\text { C }\end{array}$ & $\begin{array}{c}\mathrm{G} \\
\mathrm{G} \\
\mathrm{G} \\
\mathrm{G} \\
\mathrm{M}\end{array}$ & $\begin{array}{l}F \\
F \\
F \\
F \\
F\end{array}$ & $\begin{array}{l}F \\
F \\
F \\
F \\
F\end{array}$ & $\begin{array}{l}F \\
F \\
F \\
F \\
F\end{array}$ & & $\begin{array}{l}\mathrm{F} \\
\mathrm{F} \\
\mathrm{F}\end{array}$ & $\begin{array}{l}F \\
F\end{array}$ & $\begin{array}{l}\mathrm{F} \\
\mathrm{F}\end{array}$ \\
\hline & $\begin{array}{l}X \\
X \\
X\end{array}$ & & $X$ & & $X$ & & & $\begin{array}{l}X \\
X \\
X\end{array}$ & & & & $\begin{array}{l}X \\
X \\
X\end{array}$ & $X$ & $\begin{array}{l}\mathrm{X} \\
\mathrm{X} \\
\mathrm{X} \\
\mathrm{X} \\
\mathrm{X}\end{array}$ & $\mathrm{X}$ & & & $X$ & $\begin{array}{l}\text { C } \\
\text { C } \\
\text { F } \\
\text { C } \\
\text { F }\end{array}$ & $\begin{array}{l}M \\
G \\
M \\
G \\
G\end{array}$ & $\begin{array}{l}F \\
F \\
F \\
F \\
F\end{array}$ & $\begin{array}{l}F \\
F \\
F\end{array}$ & $\begin{array}{l}F \\
F \\
F \\
F \\
F\end{array}$ & & $\begin{array}{l}F \\
F \\
F \\
F\end{array}$ & & \\
\hline $\mathrm{X}$ & $\mathrm{X}$ & & $\begin{array}{l}X \\
X \\
X \\
X \\
X\end{array}$ & $\begin{array}{l}\mathrm{X} \\
\mathrm{X} \\
\mathrm{X}\end{array}$ & $\begin{array}{l}X \\
X \\
X\end{array}$ & & & $X$ & & $\begin{array}{l}\mathrm{X} \\
\mathrm{X} \\
\mathrm{X} \\
\mathrm{X}\end{array}$ & & $\begin{array}{l}X \\
X \\
X \\
X\end{array}$ & $X$ & & & $\begin{array}{l}\mathrm{X} \\
\mathrm{X} \\
\mathrm{X} \\
\mathrm{X}\end{array}$ & & & $\begin{array}{c}\text { C } \\
\text { VA } \\
\text { VA } \\
\text { VA } \\
\text { A }\end{array}$ & $\begin{array}{c}M \\
G \\
G \\
G \\
M\end{array}$ & $\mathrm{~F}$ & $\mathrm{~F}$ & F & & $\mathrm{F}$ & & $\mathrm{F}$ \\
\hline $\begin{array}{l}\mathrm{X} \\
\mathrm{X} \\
\mathrm{X} \\
\mathrm{X} \\
\mathrm{X}\end{array}$ & & $\begin{array}{l}\mathrm{X} \\
\mathrm{X} \\
\mathrm{X} \\
\mathrm{X}\end{array}$ & $\begin{array}{l}X \\
X \\
X \\
X \\
X\end{array}$ & $\begin{array}{l}\mathrm{X} \\
\mathrm{X} \\
\mathrm{X} \\
\mathrm{X} \\
\mathrm{X}\end{array}$ & $\begin{array}{l}X \\
X \\
X \\
X \\
X\end{array}$ & $\mathrm{X}$ & $\begin{array}{l}X \\
X\end{array}$ & & & $\begin{array}{l}\mathrm{X} \\
\mathrm{X} \\
\mathrm{X}\end{array}$ & & $\begin{array}{l}X \\
X \\
X \\
X \\
X\end{array}$ & & & & & & & $\begin{array}{l}\text { VA } \\
\text { VA } \\
\text { VA } \\
\text { VA } \\
\text { VA }\end{array}$ & $\begin{array}{l}\text { G } \\
\text { G } \\
\text { G } \\
\text { G } \\
\text { G }\end{array}$ & & $\mathrm{F}$ & F & & & & \\
\hline $\begin{array}{l}X \\
X \\
X \\
X\end{array}$ & & $\begin{array}{l}X \\
X \\
X\end{array}$ & $X$ & $\begin{array}{l}X \\
X \\
X \\
X \\
X\end{array}$ & $\begin{array}{l}X \\
X \\
X \\
X \\
X\end{array}$ & & $\begin{array}{l}\mathrm{X} \\
\mathrm{X} \\
\mathrm{X} \\
\mathrm{X} \\
\mathrm{X}\end{array}$ & & $\begin{array}{l}x \\
x\end{array}$ & & & $\begin{array}{l}\mathrm{X} \\
\mathrm{X} \\
\mathrm{X} \\
\mathrm{X} \\
\mathrm{X}\end{array}$ & & & & & & & $\begin{array}{c}\text { VA } \\
\text { VA } \\
\text { A } \\
\text { VA } \\
\text { VA }\end{array}$ & $\begin{array}{l}\mathrm{G} \\
\mathrm{G} \\
\mathrm{M} \\
\mathrm{G} \\
\mathrm{G}\end{array}$ & & & & & & & \\
\hline & $X$ & & & $\begin{array}{l}\mathrm{X} \\
\mathrm{X} \\
\mathrm{X}\end{array}$ & & & $\begin{array}{l}X \\
X \\
X\end{array}$ & & $\begin{array}{l}\mathrm{X} \\
\mathrm{X} \\
\mathrm{X}\end{array}$ & & & $\begin{array}{l}\mathrm{X} \\
\mathrm{X} \\
\mathrm{X}\end{array}$ & & & & & & & $\begin{array}{l}\text { VA } \\
\text { VA } \\
\text { VA }\end{array}$ & $\begin{array}{l}\mathrm{G} \\
\mathrm{G} \\
\mathrm{G}\end{array}$ & & & & & & & \\
\hline
\end{tabular}

500 meters above the second reflector when clathrates were cored near 378 meters sub-bottom depth.

As at Site 497, two lithostratigraphic units were noted (Fig. 10, Table 8), differing in increased sand content and induration toward the base of the hole. The upper unit is unconsolidated Quaternary mud; the lower unit ranges from lower Miocene through upper Pliocene sandy mud.

The first 225 meters (Cores 1-24) of Site 496 consist of a monotonous planktonic foraminiferal assemblage belonging to the Neogloboquadrina eggeri Zone. Faunas are dominated by $N$. eggeri, N. blowi, Globorotalia menardii, along with common Globigerinoides ruber, $G$. sacculifer, and lesser abundances of other tropical species. Pink-pigmented $G$. ruber occurs between Samples 496-1-3, 75-77 $\mathrm{cm}$ and 496-12-2, 50-52 cm; the top level corresponds to the extinction level $120,000 \mathrm{yr}$. ago, and the lower level may represent its normal limit of pigment preservation found in Pacific sediments dating from about 250,000 yr. ago.

A long interval barren of planktonic foraminifers extends from Section 496-27-1, at 256 meters to Section
496-33-5, at 308 meters, so that the middle Miocene through upper Pliocene is defined only by radiolarians (Westberg and Riedel, this volume). Species present immediately above the barren zone are Globorotalia tumida, G. menardii, dextral Pulleniatina, N. humerosa, Globoquadrina altispira, Globorotalia pseudomiocenica, and Globigerinoides obliquus; this assemblage is very similar to the one encountered in Hole 497, Core 30. Benthic foraminiferal species were typical of lower to middle bathyal depths: Globobulimina, Hoeglundina elegans, Martinottiella, Uvigerina senticosa, U. peregrina, Pyrgo, Melonis pompilioides, Sphaeroidina bulloides, Ehrenbergina. Benthic foraminifers present in the interval barren of planktonic foraminifers are rare Martinottiella and Eggerella.

Below the foraminifer-poor interval, nannofossils indicated ages near the end of the early Miocene. Planktonic foraminiferal assemblages containing Globorotalia acostaensis, Globoquadrina venezuelana, Globigerinoides venezuelana, Globigerinoides trilobus, Globigerina bulloides, Globorotalia siakensis, and Globoquad- 


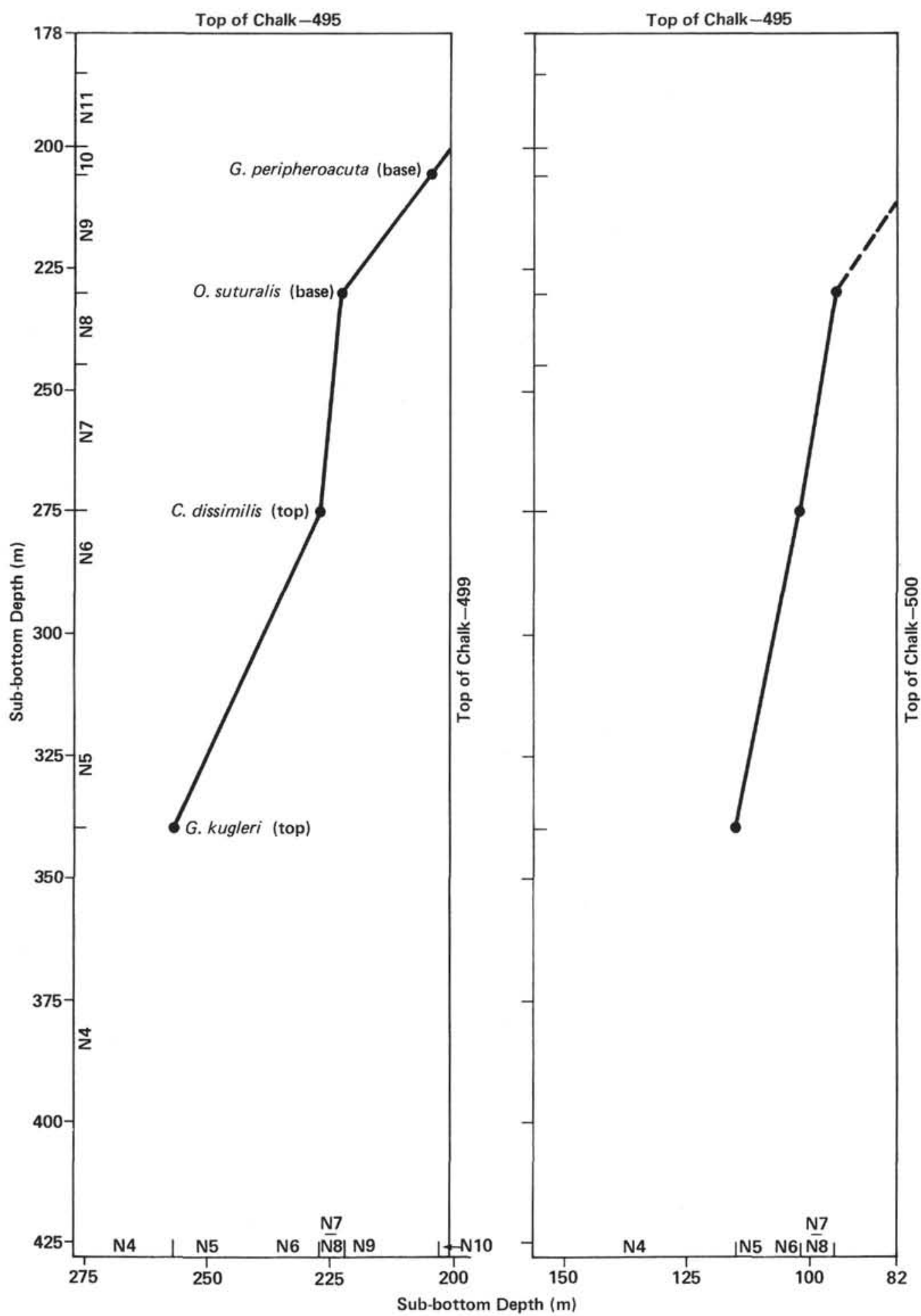

Figure 6. Correlation of the chalk in Sites 499 and 500 to Site 495 , showing location of zone boundaries and general accumulation rates. (Note that the chalk is truncated in Holes $499 \mathrm{~B}$ and 500 and that the truncation is earliest in Hole 500. No absolute basal age was assigned to these three sites due to lack of diagnostic taxa between the first appearance of G. primordius and the extinction of G. kugleri.)

rina dehiscens do not contain sufficient resolution to add more detail. Benthic foraminiferal assemblages contain Siphogenerina, Stilostomella, Robulus, and Uvigerina peregrina, suggesting shoaler depths than are indicated in higher sections.

\section{DISCUSSION}

\section{Paleobathymetry}

Planktonic and benthic foraminifers can provide important clues to the history of uplift and subsidence 


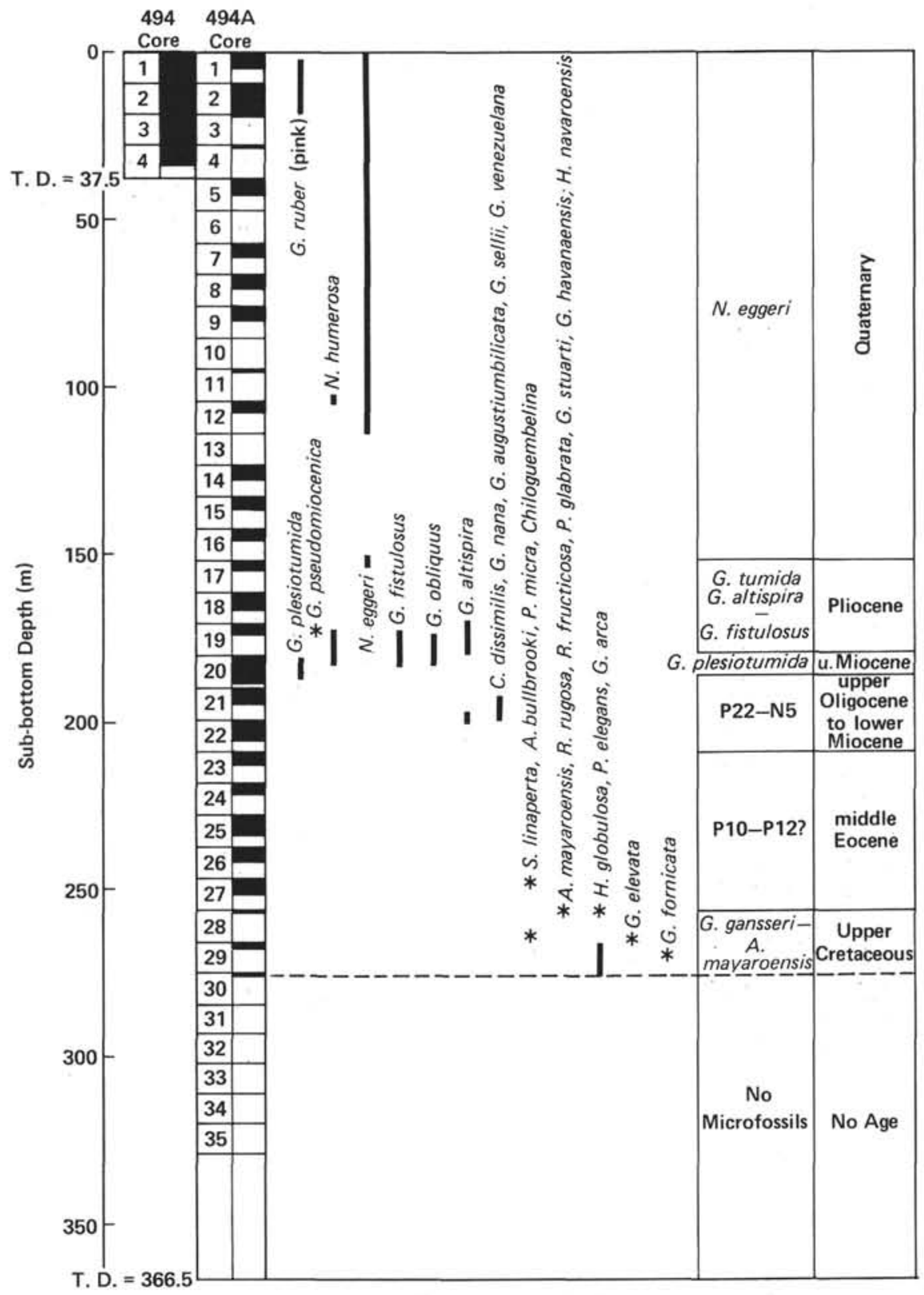

Figure 7. Range chart of planktonic foraminifers at Site 494. (Asterisks indicate the position of an isolated occurrence at the site.)

along continental margins, because it is in these regions that depth-related physio-chemical interactions with faunas are most pronounced. In situ assemblages can be expected to have a limited vertical distribution suitable for detecting downslope displacements should these conditions exist. Dissolution of calcium carbonate below the lysocline until all is destroyed near the compensation depth is particularly influential in determining the final composition of planktonic foraminiferal assemblages in sediments and thus can also be used to identify displaced materials.

Three categories of continental margin sediments can be anticipated. First, in situ sediments, identifiable in Recent materials by staining of living protoplasm, are those accumulating in sedimentologically quiescent areas.
Planktonic forms will not show fragmentation or low diversity above the lysocline, and dissolution-susceptible taxa will gradually disappear in downslope transects; benthic foraminifers identified by staining can be assumed to be in place (although they could be recently displaced) or can be zoned approximately by the most upslope occurrence of dominant types. Displaced sediments are divided into two subcategories: (1) those moved down the slope within a single benthic foraminiferal bathymetric zone and not more than several zones, and (2) those sediments clearly derived from much shoaler depths typically by turbidite motion.

Sediments that have not moved far from their source naturally can be expected to be difficult to recognize. Accurate sampling of Recent faunas that can be stained 


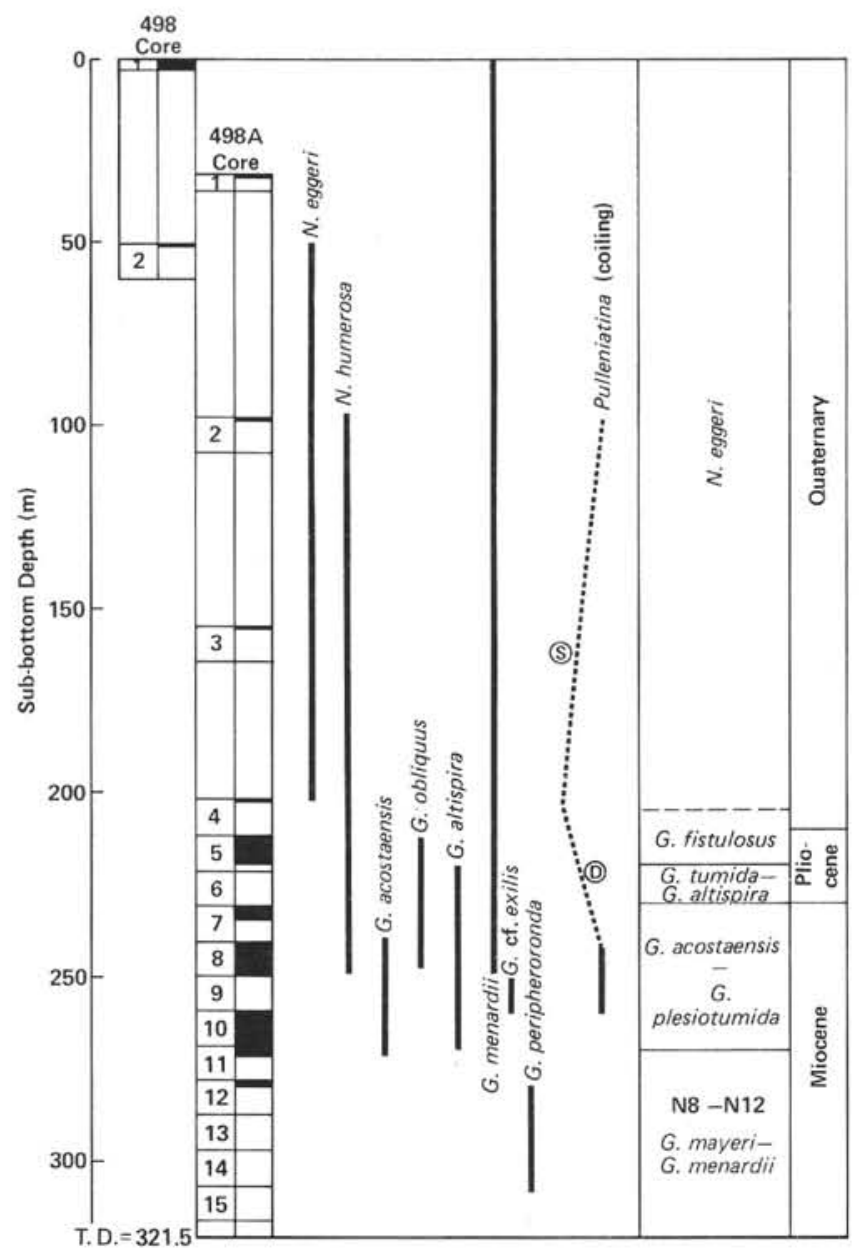

Figure 8. Range chart of planktonic foraminifers at Site 498. (D = dextral, $\mathrm{S}=$ sinistral coiling direction.)

or otherwise determined to be in place is requisite to zone the area. Fortunately, two important surveys have been made in the Leg 67 region, and both located living individuals through staining. Bandy and Arnal (1957) examined 36 samples between Acapulco and the Gulf of Panama, and Smith $(1963,1964)$ studied a transect of 22 samples off El Salvador. Both investigations recognized taxa common to the Middle America Trench region and the California borderland, but also indicated that depth boundaries based on these species were greater in the Middle America Trench sediments. Smith (1964) attributed the greater water depth ranges to warm water temperatures broadening life ranges.

Turbidite sedimentation causes the rapid translocation of shallow-water materials into deeper water. It can often be recognized sedimentologically by its graded bedding, which, however, does little to disclose its origin. Turbidites can be recognized in extreme cases by the abundance of near-shore materials such as plant fragments, mollusc shells, and shallow-water foraminifers present at depths where it is not possible that such materials could normally live.

Had the tops of the Leg 67 holes not been obliterated by the spudding-in processes, staining of the benthic foraminiferal assemblages would have allowed me to ex- tend the shelf and slope zonations of Bandy and Arnal (1957) and Smith (1964) down to and across the Middle America Trench to the Cocos Plate. It seems reasonable, nonetheless, to utilize the latest Quaternary assemblage at each site as an approximate analog of the present (Fig. 11).

The two slope locations, Sites 496 and 497, contain bathyal taxa common along the eastern Pacific margin from the California borderland to Panama, including Globobulimina pacifica, Uvigerina peregrina, U. senticosa, Bolivina seminuda, B. denudata, Melonis pompilioides, Martinottiella communis, and Eggerella bradyi. These species are apparently isobathyal on a worldwide basis (Bandy and Chierici, 1966). Site 494 at the base of the slope and considerably deeper than Site 496 and 497, also has a similar benthic foraminiferal composition. I cannot tell at this point whether this faunal similarity reflects broad habitats with little faunal variation or whether the site is receiving from upslope displaced foraminifers that have not been morphologically affected by downslope transport.

I noted no abyssal assemblage per se characterizing the Trench in Sites 499 and 500, a feature previously noted by Smith (1964). Further south in the Peru-Chile Trench, agglutinated species dominate the abyssal to hadal depths (Bandy and Rodolfo, 1964; Ingle et al., 1980). Instead, coarse sandy turbidites characterize the Middle America Trench at Leg 67 sites bearing plant debris, ostracodes, mollusc fragments, echinoid spines, and shallow-water foraminifers, such as Ammonia, Elphidium, and Textularia. These samples have the shallowest-origin materials seen from the transect, and none of these materials were as abundant at the other sites. It is my opinion that these turbidites are being fed to the Trench via the submarine canyon off San José, Guatemala (Fig. 1) and moved axially along the Trench (see Shiki et al., this volume). The lack of similar components in slope sediments except near the top of Site 494 indicates that the trench-fill turbidites bypass the slope, and that a less dynamic mode of foraminiferal displacement operates on the slope.

Smith (1964) has pointed out that the shelf fauna off El Salvador is similar to Pleistocene assemblages exposed on islands in the Gulf of California and that the slope fauna is similar to California Pliocene beds described by Natland (1950). Certain elements lacking in the late Cenozoic faunas from California but common off Central America at present (large species of Cancris and Valvulinerina) are, however, abundant in the Miocene of California. These occurrences speak of a combination of basin migration southward through time and ecological restrictions accompanying climatic deteriorations in the Cenozoic. In the Pleistocene particularly, extratropical species such as $N$. pachyderma and $G$. inflata invaded the Panama Basin area (Keigwin, 1976; Thompson, 1976); these taxa are abundant in the coarse sediments, suggesting turbidite origin-perhaps lowered sea levels eroded deposits more actively at these glacial stages.

Before the tectonic history of this region can be fully appreciated, it will be imperative, in future work on 
these sites, to separate vital effects from depositional ones to establish a reasonable bathymetric and environmental interpretation of fossil assemblages along the Middle America continental margin.

\section{Leg 67 Pre-Quaternary Sediments}

In Leg 67 Sites 495, 499, and 500, the oceanic Cocos Plate has lower Miocene chalk lying conformably on basalt basement (Fig. 12). The chalk is overlain by a brown abyssal clay barren of carbonate, interpreted as sediment acquired when the Plate passed out of the equatorial carbonate belt and beneath less fertile waters of the subtropical region. The most recent capping layers are hemipelagic muds accumulated when the plate neared its modern position and gradually came under the influence of coastal upwelling and terrigenous deposition.

Site 494 at the base of the landward slope displays, at drilling depths comparable to the ocean-plate sequence, a sequence composed of Maestrichtian calcareous claystone, overlain by middle Eocene volcanic mudstones, topped by Miocene to Quaternary hemiterrigenous mudstones. Further upslope at Sites 496 and 497, the upper Cenozoic sediments are generally similar to those at Site 494 , but coarser. At no location landward of the Trench were chalks encountered, indicating that subduction rather than accretion has been the dominant tectonic process since at least the Miocene. The truncation of lowest middle Miocene sections at Sites 499 and 500 may indicate timing of the present phase of plate subduction and/or tectonic erosion.

Many stratigraphic sections of Central America adjacent to the Leg 67 transect show the Maestrichtian-middle Eocene-upper Cenozoic sequence seen at Site 494 (Fig. 12). Key compilations of the stratigrap - of the region include Cooke et al., 1943; Vinson, 19o2; Henningsen, 1968; Dengo, 1962; Bandy, 1970; Kuipers, 1980; and Weyl, 1980. The Esso Petrel No. 1 well (Seely, 1979), upslope from the Leg 67 transect, shows similar gaps seen throughout the region but also a thick Paleocene to Eocene interval that rarely occurs on land. The regional significance of these hiatuses has been attributed variously to episodic subduction (Karig et al., 1978), episodic uplift of the fore-arc basin (Seely, 1979), and periodic shifts of the CCD (van Andel et al., 1975). A combination of these processes has likely contributed to the development of this complicated active margin. Deep ocean drilling in the future is necessary to solve the problems that have only begun to be described.

\section{CONCLUSIONS}

1. The subducting Cocos Plate has lower Miocene chalk lying conformably on oceanic basalt. The base of the landward slope at comparable water depths contains Maestrichtian carbonates, middle Eocene volcanic mudstones, and Miocene to Quaternary mudstones. These juxtaposed sequences indicate that subduction rather than accretion has been the dominant tectonic process since the Miocene.

2. Sediment displacements and turbidites are the most common modes of sedimentation on the lower slope and trench. Planktonic foraminifers are well pre- served despite their occurrence below the modern CCD. Benthic foraminifers have living representatives at much shallower depths. Displacement was apparently contemporaneous with deposition because the biostratigraphy is not upset.

3. No in situ Trench benthic foraminiferal assemblage was observed. The Trench is presently being filled with coarse near-shore sands that are funneled to it by a submarine canyon off San José, Guatemala, bypassing the slope.

4. Correlation of the DSDP sites to published sections in Guatemala, Costa Rica, and the Canal Zone show the widespread occurrence of three unconformities-Maestrichtian-middle Eocene, middle Eocenelower Miocene and middle-upper Miocene. These unconformities may be related to episodes of tectonic activity gradually building Central America.

\section{ACKNOWLEDGMENTS}

I wish to thank G. Dengo and G. Escalante for hosting the postcruise field excursion to the Nicoya Peninsula of Costa Rica. A. Boersma was most helpful in corroborating my identification of the Upper Cretaceous taxa from Site 494. L. D. Keigwin, Jr., W. T. Coulbourn, and A. Boersma made many constructive suggestions as reviewers.

\section{REFERENCES}

Bandy, O. L., 1970. Upper Cretaceous-Cenozoic paleobathymetric cycles, Eastern Panama and Northern Colombia. Trans. Gulf Coast Assoc. Geol. Soc., 20:181-193.

Bandy, O. L., and Arnal, R. E., 1957. Distribution of Recent foraminifera off west coast of Central America. Bull. Am. Assoc. Petrol. Geol., 41(9):2037-2053.

Bandy, O. L., and Chierici, M., 1966. Depth-temperature evaluation of selected California and Mediterranean bathyal foraminifera. Mar. Geol., 4:259-271.

Bandy, O. L., and Rodolfo, K. S., 1964. Distribution of foraminifèra and sediments, Peru-Chile Trench area. Deep-Sea Res., 11: 817-837.

Berggren, W. A., 1973. The Pliocene time scale: calibration of planktonic foraminifera and calcareous nannoplankton zones. Nature, 243:391-397.

Blow, W. H., 1969. Late Middle Eocene to Recent planktonic foraminiferal biostratigraphy. In Brönnimann, P., and Renz, H. H. (Eds.), Proceedings of the First International Conference on Planktonic Microfossils (Vol. 1): Leiden (E. J. Brill), 199-421.

Blow, W. H., and Banner, F. T., 1966. The morphology, taxonomy and biostratigraphy of Globorotalia barisanensis Leroy, Globorotalia fohsi Cushman and Ellisor, and related taxa. Micropaleontology, 12(3):286-302.

Bolli, H. M., 1959. Planktonic foraminifera as index fossils in Trinidad, West Indies, and their value for worldwide stratigraphic correlations. Eclogae Geol. Helv., 52:627-637. 1966. Zonation of Cretaceous to Pliocene marine sediments based on planktonic foraminifera. Bol. Inf. Asoc. Venez. Geol. Min. Pet., 9:3-32.

Brönnimann, P., and Resig, J., 1971. A Neogene globigerinacean biochronologic time-scale of the southwestern Pacific. In Winterer, E. L., Riedel, W. R., et al., Init. Repts. DSDP, 7, Pt. 2: Washington (U.S. Govt. Printing Office), 1235-1469.

Cooke, C. W., Gardner, J., and Woodring, W. P., 1943. Correlation of the Cenozoic formations of the Atlantic and Gulf coastal plain and the Caribbean region. Bull. Geol. Soc. Am., 54:1713-1723.

Crescenti, U., 1966. Sulla biostraigrafia del Miocene affiorante al confine marchigiano-abruzzese. Geol. Rom., 5:1-54.

Dengo, G., 1962. Tectonic-igneous sequence in Costa Rica. In Engel, A. E., James, H. L., and Leonard, B. F. (Eds.), Petrologic Studies: a Volume in Honor of A. F. Buddington: Geol. Soc. Am., pp. 133-161. 
Heezen, B. C., and Fornari, D., 1975. Geological map of the Pacific Ocean. In Andrews, J. E., Packham, G., et al., Init. Repts. DSDP, 30: Washington (U.S. Govt. Printing Office), back pocket.

Henningsen, D. W., 1968. Stratigraphy and paleogeography of the Upper Cretaceous and Tertiary sediments in southern Costa Rica. In Saunders, J. B. (Ed.), Trans., 4th Caribbean Geol. Conf., Trinidad, 1965 , pp. $353-356$

Ingle, J. C., Jr., Keller, G., and Kolpack, R. L., 1980. Benthic foraminiferal biofacies, sediments and water masses of the southern Peru-Chile Trench area, southeastern Pacific Ocean. Micropaleontology, 26(2):113-150.

Jenkins, D. G., and Orr, W. N., 1972. Planktonic foraminiferal biostratigraphy of the eastern Pacific. In Hays, J. D., et al., Init. Repts. DSDP, 9: Washington (U.S. Govt. Printing Office), 1059-1194.

1980. Eastern equatorial Pacific Pliocene-Pleistocene biostratigraphy. In Sliter, W. V. (Ed.), Studies in Marine Micropaleontology, a Memorial Volume to Orville L. Bandy. Cushman Found. Foraminiferal Res., Spec. Publ., 19:278-286.

Kaneps, A. G., 1973. Cenozoic planktonic foraminifera from the eastern Equatorial Pacific Ocean. In van Andel, Tj. H., Heath, G. R., et al., Init. Repts. DSDP, 16: Washington (U.S. Govt. Printing Office), 713-745.

Karig, D. E., Cardwell, R. K., Moore, G. F., and Moore, D. G., 1978. Late Cenozoic subduction and continental margin truncation along the northern Middle America Trench. Geol. Soc. Am. Bull., 89:265-276.
Keigwin, L. D., Jr., 1976. Late Cenozoic planktonic foraminiferal biostratigraphy and paleoceanography of the Panama Basin. Micropaleontology, 22(4):419-442.

, 1978. Pliocene closing of the Isthmus of Panama, based on biostratigraphic evidence from nearby Pacific Ocean and Caribbean Sea cores. Geology, 6(10):630-634.

Kuipers, E. P., 1980. The geologic history of the Nicoya Complex, Costa Rica, and its geotectonic significance. Tectophysics, 68(3/4): 233-256.

LaBrecque, J. L., Kent, D. V., and Cande, S. C., 1977. Revised magnetic polarity time scale for late Cretaceous and Cenozoic time. Geology, 5(6):330-335.

Natland, M. L., 1950. The 1940 E. W. Scripps cruise to the Gulf of California: Pt. 4, report on the Pleistocene and Pliocene foraminifera. Geol. Soc. Am., Mem., 43, Pt. 4:1-55.

Premoli Silva, I., and Bolli, H. M., 1973. Late Cretaceous to Eocene planktonic foraminifera and stratigraphy of Leg 15 sites in the Caribbean Sea. In Edgar, N. T., Saunders, J. B., et al., Init. Repts. DSDP, 15: Washington (U.S. Govt. Printing Office), 499-547.

Saito, T., 1976. Geological significance of coiling direction in the planktonic foraminifera Pulleniatina. Geology 4(5):305-309.

Seely, D. R., 1979. The evolution of structural highs bordering major forearc basins. In Watkins, J. S., Montadert, L., and Dickerson, P. W. (Eds.), Geological and Geophysical Investigations of Continental Margins: Am. Assoc. Pet. Geol., Mem., 29:245-260.

Table 6. Planktonic foraminifers and other microconstituents at Site 498.

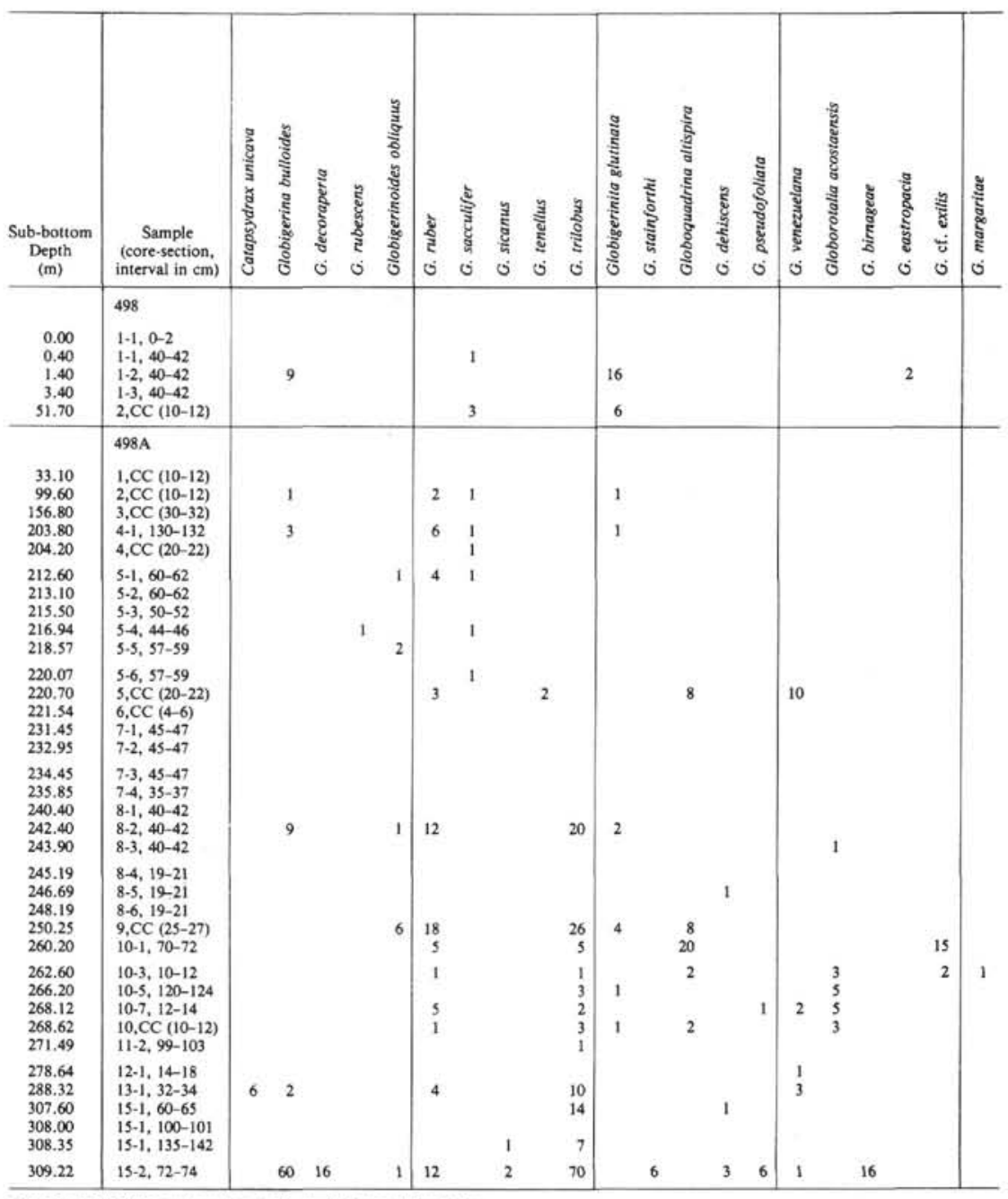

Note: See Table 2 for explanation of the symbols and abbreviations. 
Seely, D. R., Vail, P. R., and Walton, G. G., 1974. Trench slope model. In Burk, C. A., and Drake, C. L. (Eds.), The Geology of Continental Margins: New York (Springer Verlag), pp. 249-260.

Smith, P. B., 1963. Quantitative and qualitative analysis of the family Bolivinidae; Recent Foraminifera off Central America. U.S. Geol. Surv. Prof. Pap., 429-A.

1964. Ecology of benthonic species. U.S. Geol. Surv. Prof. Pap., 429-B.

Thompson, P. R., 1976. Planktonic foraminiferal dissolution and the progress towards a Pleistocene equatorial Pacific transfer function. J. Foraminiferal Res., 6(3):208-227.

Thompson, P. R., Bé, A. W. H., Duplessy, J.-C., and Shackleton, N. J., 1979. Disappearance of pink-pigmented Globigerinoides ruber at $120,000 \mathrm{yrBP}$ in the Indian and Pacific oceans. Nature, 280(5723):554-558.

Thompson, P. R., and Sciarrillo, J. R., 1978. Planktonic foraminiferal biostratigraphy in the equatorial Pacific. Nature, 276(5683): 29-33.

van Andel, Tj. H., Heath, G. R., and Moore, T. C., Jr., 1975. Cenozoic History and Paleoceanography of the Central Equatorial Pacific Ocean. Geol. Soc. Am. Mem. 143.

van den Bold, W. A., 1963. Ostracodes and Tertiary stratigraphy of Guatemala. Bull. Am. Assoc. Pet. Geol., 47(4):696-698.

1966. Ostracode zones in Caribbean Miocene. Bull. Am. Assoc. Pet. Geol., 50(5):1029-1031.

Vinson, G. L., 1962. Upper Cretaceous and Tertiary stratigraphy of Guatemala. Bull. Am. Assoc. Pet. Geol., 46(4):425-456.
Weyl, R., 1980. Geology of Central America: Berlin (Gebruder Borntraeger).

Woodring, W. P. and Thompson, T. F., 1949. Tertiary formations of Panama Canal Zone and adjoining parts of Panama. Bull. Am. Assoc. Pet. Geol., 33(2):223-247.

\section{APPENDIX}

\section{Taxonomic Notes}

Neogloboquadrina blowi Rògl and Bolli, 1973, p. 570, pl. 9, figs. 1922 ; pl. 17 , fig. 12 (nom, nov. Globigerina subcretacea Chapman, 1902 , p. 410 , pl. 36 , fig. 13 ).

This species is common from the Pliocene to Recent in Pacific sediments and can be recognized by the typical four and one-half well-inflated chambers in the final whorl.

Neogloboquadrina eggeri (Rhumbler) [=Globigerina eggeri Rhumbler, 1901, p. 19, tf. 20 a-c].

This species is abundant in the upwelling region of the eastern equatorial Pacific and can be recognized by the low trochospire of five to seven globular but slowly enlarging chambers per whorl.

Neogloboquadrina pachyderma (Ehrenberg) [=Aristerospira pachyderma Ehrenberg, 1861, pp. 276, 277, 303, pl. 1, fig. 4; also = Globigerina bulloides var. borealis Brady, 1881, p. 412].

It is difficult to be certain that Ehrenberg's species is synonymous with Brady's, although most later workers feel that Ehrenberg has priority. The better-illustrated Brady form is understood here to be the morphotype of "pachyderma." In the eastern

Table 6. (Continued).

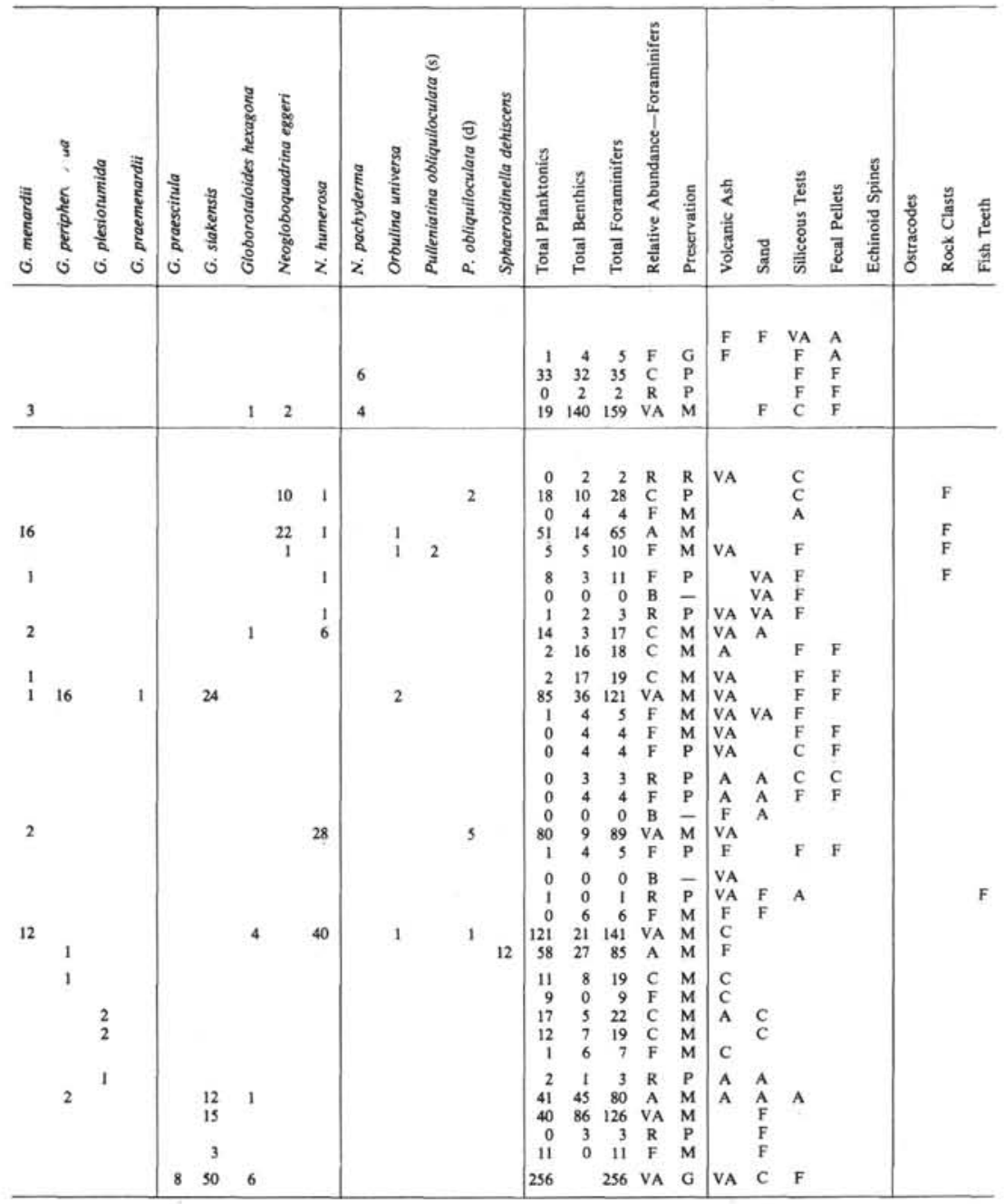




\section{P. R. THOMPSON}

Pacific, the dextral coiling variety is common in modern sediments (Thompson, 1976), and the sinistral coiling form indicative of cold waters can be interpreted as marking glacial stages of the Quaternary. Both varieties can be separated from small N. blowi or N. eggeri by the thick apertural rim flush with the base of the final chamber.

Globigerinoides ruber (d'Orbigny) [= Globigerina rubra d'Orbigny, 1838 a, p. 82 , pl. 4 , figs. $12-14]$.

The white form can be found from the middle Miocene to Recent, but the pink-pigmented form occurred only from 250,000 to $120,000 \mathrm{yr}$. ago in the Indo-Pacific (Thompson et al., 1979). The dark red colored individuals abundant in the Atlantic are represented in the Pacific by pale pink colored specimens. The lower limit of stratigraphic occurrence is variable because of decomposition of the pigment.

Globigerinoides bulloideus Crescenti, 1966, p. 43, tf. 8, fig. 3; tf. 9, fig. 9.

The species ranges from middle Miocene to upper Miocene and is also observed at Sites 84, 158, and 502 (L. Keigwin, personal communication, 1981). It is similar in morphology to Globigerine bulloides but displays a prominent supplementary aperture on the spiral side at the intersection of the final and antepenultimate chambers with the spiral suture.

Globoquadrina altispira (Cushman and Jarvis) [=Globigerina altispira Cushman and Jarvis, 1936, p. 5, pl. 1, figs. 13-14]

A very characteristic species for the latter half of the lower Miocene to middle Pliocene. It is relatively resistant to dissolution and has an extinction level dated at about 2.8 Ma (Berggren, 1973). Both low and high trochospiral forms were seen but not separated.

Globoquadrina pseudofoliata Parker, 1967, pp. 170, 171, pl. 27, figs 1-3.

This large-diameter but fairly low-trochospire species is readily recognized by the rapidly inflating chambers and well-developed umbilical tooth. It disappears near the Pliocene/Pleistocene boundary in the Leg 67 samples, but did not become extinct in the Pacific until about 220,000 years ago (Thompson, 1976). Quaternary climatic deteriorations affecting circulation in the Panama Basin region apparently forced this species westward.

Globoquadrina venezuelana (Hedberg) $[=$ Globigerina venezuelana Hedberg, 1937, p. 681, pl. 92, fig. 7].

This large, robust, well-inflated species ranges from the Oligocene to the middle of the Pliocene. Mature specimens often show a flattening of the final chambers due to a greater expansion in the plane of coiling than overall chamber inflation; one or more umbilical teeth may occasionally be found, but this is not always a useful identification criterion. G. conglomerata may be a late Quaternary descendant; it first appears in Pacific piston cores dated about $600,000 \mathrm{yr}$. old (Thompson and Sciarrillo, 1978) but is then fully developed; no overlap with $G$. venezuelana has been noted by the author

Clavatorella bermudezi (Bolli) [= Hastigerinella bermudezi Bolli, 1957 , p. 112 , pl. 25 , fig. 1a-c]

This distinctive species with clavate chambers in the final whorl was found in abundance at Site 499 and 500. The gross mor- phology of this taxon is so similar to $G$. hexagona (except for the clavate chambers) that some evolutionary connection must exist.

Globorotalia cf. exilis Jenkins and Orr, 1972, p. 1098, pl. 23, figs. 1$9(?=$ Globorotalia (Globorotalia) cultrata subsp. exilis Blow, 1969 , pp. 369,397 , pl. 7 , figs. 1-3; pl. 42, figs. 1,5 ).

A thickened species morphologically similar to $G$. exilis was seen by Jenkins and Orr (1972) and also at Sites 497 and 498. It bears the slightly depressed spiral suture and partially limbate intercameral sutures of typical $G$. exilis, but is also more heavily calcified and could be a local variant of $G$. menardii.

Globorotalia menardii (Parker, Jones, and Brady) [= Rotalia menardii Parker, Jones, and Brady, 1865, p. 20, pl. 3, fig. 81].

Despite its worldwide occurrence, this species is rather variable in its morphology, which has contributed to the nomenclatural problems associated with the entire " $G$. menardii/ $G$. cultrata complex."'Forms referrable to this species from the Panama Basin area are less inflated and less calcified than comparable size individuals found in most equatorial Pacific piston cores. Most $\mathrm{Pa}$ cific specimens, in fact, are morphologically between $G$. menardii and $G$. tumida, an observation perhaps leading Brönnimann and Resig (DSDP Leg 7, 1971, pp. 1276-1277, pl. 29, fig. 3; pl. 49, fig. $4,5)$ to propose the subspecies $G$. tumida lata. Leg 67 specimens of $G$. menardii from the upper Miocene to middle Pliocene frequently show an inflation of the chambers on the spiral side creating a deep spiral sutural groove.

Globorotalia pertenuis Beard, 1969, pp. 552-553, pl. 1, figs. 1-6; pl. 2 , figs. 5,6 ; pl. 3 , fig. 4 .

Rare specimens tentatively assigned to this species were found in Sections 495-9-5 and 497-27-1 and have also been collected from Site 503 (L. Keigwin, personal communication, 1981). These shells show the large apertural tooth at the base of each chamber that coalesces to block the umbilicus. These individuals are the first known occurrences outside the Caribbean and constitute important evidence for the planktonic foraminiferal provincialism that developed in the Pacific and Caribbean following the middle Pliocene closure of the Panama Isthmus.

Globorotalia plesiotumida Banner and Blow = Globorotalia (Globorotalia) tumida subsp. plesiotumida Banner and Blow, 1965, p. 1353 , tf. 2 .

This species is an important biostratigraphic marker for the upper Miocene. Its significance in Leg 67 samples is that it provides a constraint on the highly dissolved interval ranging from the middle to upper Miocene on the margin of this tectonically active region. It is not very abundant, but is relatively durable in the sediments.

Globorotalia praemiocenica Lamb and Beard, 1972, p. 55, 56, pl. 17, figs. 1-3.

Fairly large globorotaliids with an nearly flat spiral side have been observed by Jenkins and Orr (1972, pl. 28, figs. 1-3; pl. 30, figs. 7-9) and also at Leg 67 Sites 495 and 497 . Because no true $G$. miocenica have been reported from the Pacific, this species provides additional information on the ecological changes accompanying the closing of the Panama Isthmus. 


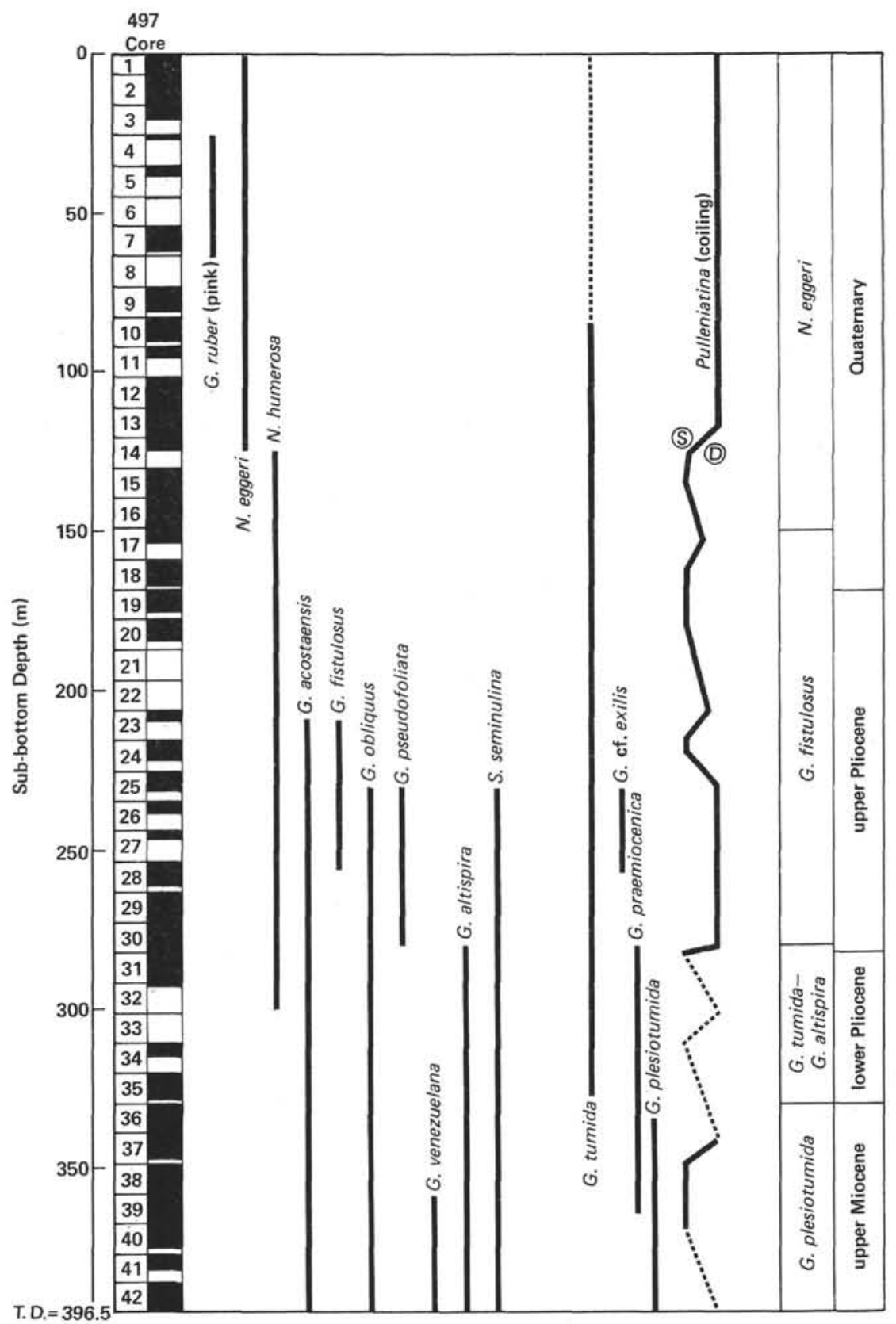

Figure 9. Range chart of planktonic foraminifers at Site 497. ( $D=$ dextral, $S=$ sinistral coiling direction.) 


\section{P. R. THOMPSON}

Table 7. Planktonic foraminifers and other microconstituents at Site 497.

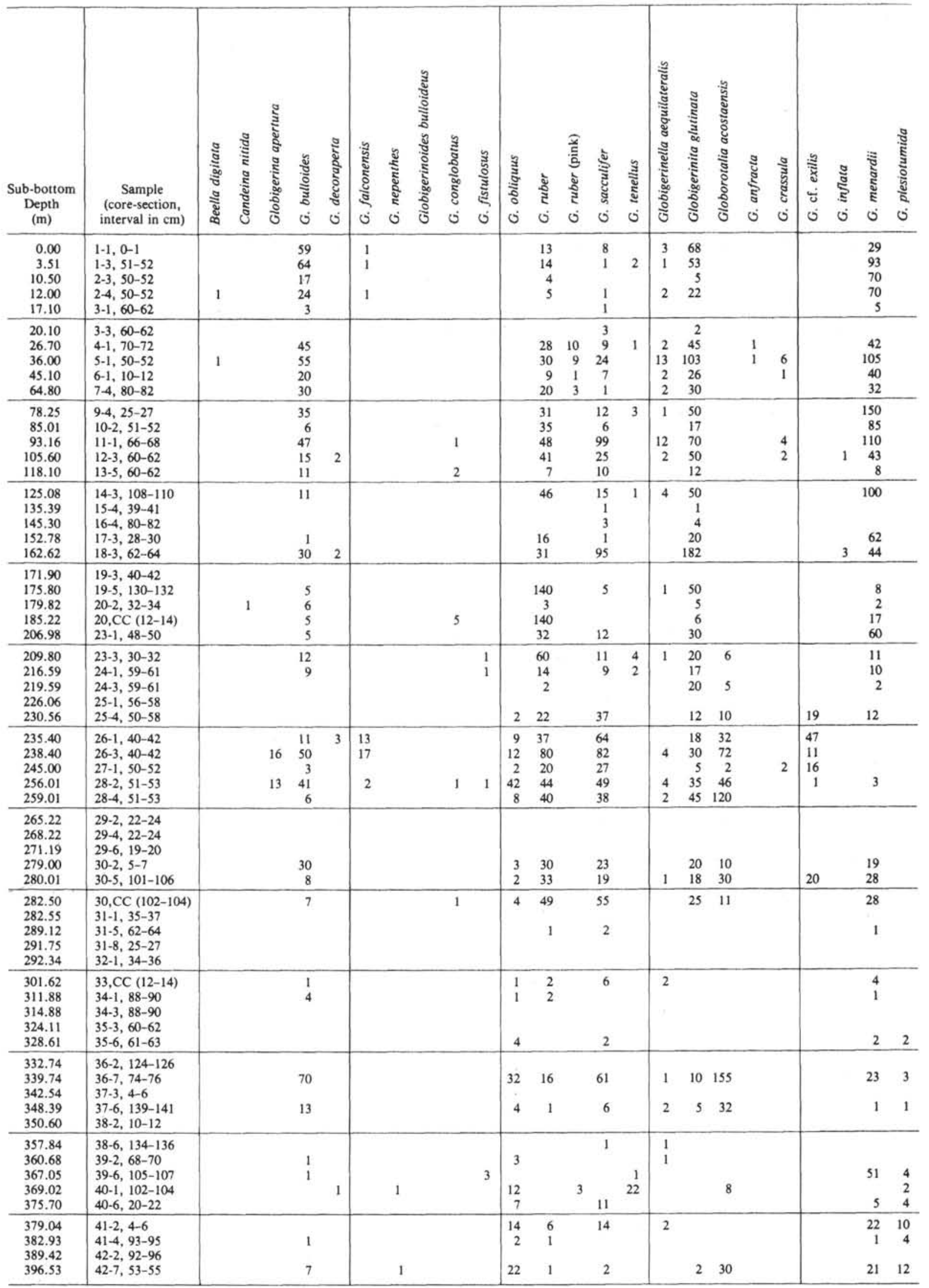

Note: See Table 2 for an explanation of symbols and abbreviations. 
Table 7. (Continued).

\begin{tabular}{|c|c|c|c|c|c|c|c|c|c|c|c|c|c|c|c|c|c|c|c|c|c|c|c|c|c|c|c|}
\hline 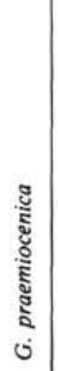 & 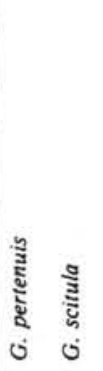 & $\begin{array}{l}\frac{8}{8} \\
\text { E } \\
0\end{array}$ & 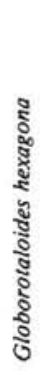 & 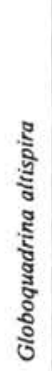 & 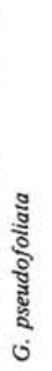 & 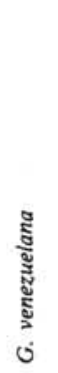 & 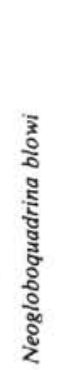 & 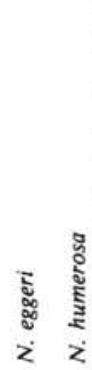 & $\begin{array}{l}\text { हूँ } \\
\text { ปัँ } \\
\text { हूँّ } \\
\Sigma \\
z\end{array}$ & 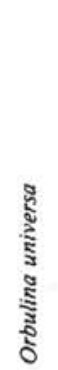 & 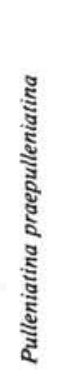 & 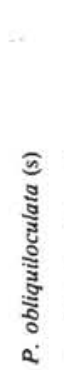 & 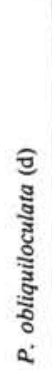 & 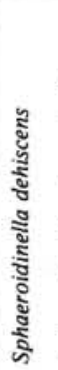 & 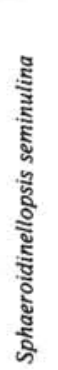 & 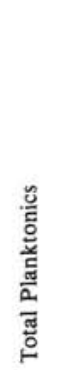 & 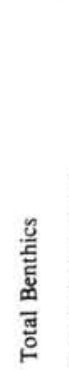 & 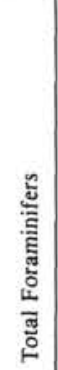 & 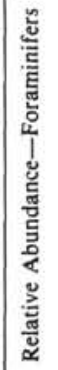 & 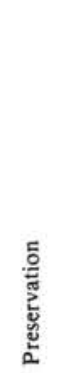 & $\begin{array}{l}\frac{5}{y} \\
\frac{y}{5} \\
\frac{\tilde{J}}{0} \\
\text { > }\end{array}$ & 可 & 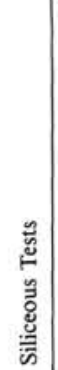 & 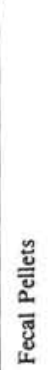 & 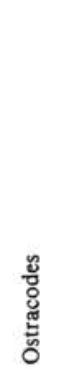 & 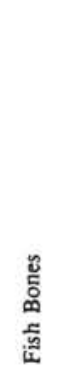 & 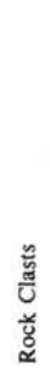 \\
\hline & 2 & & $\begin{array}{l}2 \\
1 \\
4\end{array}$ & & & & $\begin{array}{r}82 \\
151 \\
96 \\
123 \\
6\end{array}$ & $\begin{array}{r}38 \\
95 \\
12 \\
13 \\
5\end{array}$ & $\begin{array}{r}3 \\
27 \\
3 \\
16\end{array}$ & $\begin{array}{l}2 \\
2\end{array}$ & & & $\begin{array}{l}2 \\
4 \\
1 \\
1\end{array}$ & & & $\begin{array}{r}308 \\
512 \\
209 \\
283 \\
20\end{array}$ & $\begin{array}{rr}88 & 3 \\
57 & 5 \\
61 & 2 \\
85 & 3 \\
148 & 1\end{array}$ & $\begin{array}{l}396 \\
569 \\
270 \\
368 \\
168\end{array}$ & $\begin{array}{l}\text { VA } \\
\text { VA } \\
\text { VA } \\
\text { VA } \\
\text { VA }\end{array}$ & $\begin{array}{c}\text { G } \\
\text { VG } \\
\text { VG } \\
\text { VG } \\
\text { G }\end{array}$ & $\begin{array}{l}\mathrm{A} \\
\mathrm{C} \\
\mathrm{F} \\
\mathrm{F} \\
\mathrm{F}\end{array}$ & & $\begin{array}{c}\text { VA } \\
\text { C } \\
F \\
F \\
F\end{array}$ & & 1 & $\begin{array}{l}F \\
F\end{array}$ & \\
\hline & & & $\begin{array}{r}5 \\
12 \\
2 \\
1 \\
\end{array}$ & & & & $\begin{array}{r}2 \\
181 \\
141 \\
90 \\
80 \\
\end{array}$ & $\begin{array}{l}24 \\
19 \\
24 \\
24 \\
\end{array}$ & $\begin{array}{r}45 \\
1 \\
22 \\
1 \\
\end{array}$ & $\begin{array}{l}4 \\
3 \\
3 \\
\end{array}$ & & & 1 & & & $\begin{array}{r}7 \\
476 \\
520 \\
247 \\
231 \\
\end{array}$ & $\begin{array}{rr}17 \\
31 & 5 \\
73 & 5 \\
108 & 3 \\
47 & 2 \\
\end{array}$ & $\begin{array}{r}24 \\
507 \\
593 \\
355 \\
278 \\
\end{array}$ & \begin{tabular}{|l} 
C \\
VA \\
VA \\
VA \\
VA \\
\end{tabular} & $\begin{array}{l}P \\
G \\
G \\
G \\
G \\
\end{array}$ & & & $\begin{array}{l}\text { A } \\
\text { A } \\
\text { F } \\
\text { F }\end{array}$ & & $\begin{array}{c}1 \\
1 \\
\end{array}$ & $\mathrm{~F}$ & \\
\hline & & 1 & $\begin{array}{l}9 \\
3 \\
1 \\
2\end{array}$ & & & & $\begin{array}{r}60 \\
56 \\
100 \\
10\end{array}$ & $\begin{array}{rr}75 & \\
7 & \\
40 & \\
57 & 30 \\
17 & \end{array}$ & $\begin{array}{l}15 \\
4\end{array}$ & $\begin{array}{r}26 \\
1 \\
21 \\
5\end{array}$ & 23 & & $\begin{array}{l}1 \\
1 \\
1\end{array}$ & & & $\begin{array}{r}468 \\
217 \\
558 \\
426 \\
85\end{array}$ & $\begin{array}{rr}48 & 5 \\
134 & 3 \\
101 & 6 \\
46 & 4 \\
155 & 2 \\
\end{array}$ & $\begin{array}{l}516 \\
351 \\
659 \\
472 \\
240\end{array}$ & $\begin{array}{l}\text { VA } \\
\text { VA } \\
\text { VA } \\
\text { VA } \\
\text { VA }\end{array}$ & $\begin{array}{l}\mathrm{G} \\
\mathrm{G} \\
\mathrm{G} \\
\mathrm{G} \\
\mathrm{G}\end{array}$ & & & & & 2 & & \\
\hline & 1 & & $\begin{array}{r}11 \\
1\end{array}$ & 3 & & & $\begin{array}{r}50 \\
1 \\
10 \\
85 \\
8\end{array}$ & $\begin{array}{ll}125 & 2 \\
& \\
52 & \\
& 10\end{array}$ & $\begin{array}{r}24 \\
2 \\
20 \\
\end{array}$ & $\begin{array}{r}1 \\
1 \\
16\end{array}$ & & $\begin{array}{r}8 \\
5 \\
4 \\
46 \\
\end{array}$ & 12 & & & $\begin{array}{r}461 \\
4 \\
23 \\
165 \\
575 \\
\end{array}$ & $\begin{array}{rr}91 & 5 \\
68 & \\
5 & \\
161 & 3 \\
147 & 7 \\
\end{array}$ & \begin{tabular}{r|}
552 \\
72 \\
28 \\
326 \\
722 \\
\end{tabular} & $\begin{array}{c}\text { VA } \\
\text { A } \\
\text { C } \\
\text { VA } \\
\text { VA }\end{array}$ & $\begin{array}{c}\mathrm{G} \\
\mathrm{P} \\
\mathrm{P} \\
\mathrm{M} \\
\mathrm{G} \\
\end{array}$ & $\begin{array}{c}\text { VA } \\
\text { F } \\
\text { F }\end{array}$ & & $\begin{array}{l}\mathrm{F} \\
\mathrm{F} \\
\mathrm{F}\end{array}$ & & & $F$ & \\
\hline & & 16 & $\begin{array}{l}2 \\
1 \\
4\end{array}$ & & & & $\begin{array}{r}35 \\
3 \\
7 \\
36 \\
\end{array}$ & $\begin{array}{r}17 \\
2 \\
19 \\
30\end{array}$ & & $\begin{array}{r}5 \\
1 \\
2 \\
12\end{array}$ & & $\begin{array}{r}28 \\
1 \\
3\end{array}$ & 2 & & & $\begin{array}{r}0 \\
296 \\
25 \\
91 \\
226\end{array}$ & $\begin{array}{rr}22 & \\
315 & 6 \\
227 & 2 \\
363 & 4 \\
117 & 3 \\
\end{array}$ & $\begin{array}{r}22 \\
611 \\
252 \\
454 \\
343 \\
\end{array}$ & \begin{tabular}{|l} 
C \\
VA \\
VA \\
VA \\
VA \\
\end{tabular} & $\begin{array}{l}\mathrm{M} \\
\mathrm{G} \\
\mathrm{M} \\
\mathrm{M} \\
\mathrm{G}\end{array}$ & $\begin{array}{l}\text { VA } \\
\text { VA } \\
\text { VA }\end{array}$ & & \begin{tabular}{c|}
$\mathrm{F}$ \\
$\mathrm{F}$ \\
$\mathrm{F}$ \\
$\mathrm{F}$ \\
VA
\end{tabular} & & & F & \\
\hline & 2 & & $\begin{array}{l}5 \\
5 \\
7\end{array}$ & & 6 & & $\begin{array}{r}4 \\
2 \\
40\end{array}$ & $2^{14}$ & 10 & $\begin{array}{l}4 \\
2\end{array}$ & & 16 & 17 & & 5 & $\begin{array}{r}151 \\
80 \\
48 \\
0 \\
222 \\
\end{array}$ & $\begin{array}{rr}232 & 3 \\
809 & 8 \\
88 & 1 \\
0 & \\
75 & 2 \\
\end{array}$ & $\begin{array}{r}383 \\
889 \\
136 \\
0 \\
297\end{array}$ & \begin{tabular}{|l} 
VA \\
VA \\
VA \\
B \\
VA \\
\end{tabular} & $\begin{array}{l}G \\
G \\
G \\
\bar{G}\end{array}$ & $\begin{array}{c}\text { VA } \\
\text { A }\end{array}$ & & $\begin{array}{l}\text { VA } \\
\text { C } \\
\text { C }\end{array}$ & & & & $\mathrm{F}$ \\
\hline & $\begin{array}{lr}2 & 9 \\
17 \\
\end{array}$ & $\begin{array}{r}10 \\
17 \\
8 \\
4 \\
4 \\
\end{array}$ & $\begin{array}{r}6 \\
14 \\
5 \\
4 \\
29 \\
\end{array}$ & 1 & $\begin{array}{l}3 \\
1\end{array}$ & $\begin{array}{l}20 \\
10 \\
\end{array}$ & $\begin{array}{l}60 \\
40 \\
10\end{array}$ & $\begin{array}{rr} & 30 \\
& 22 \\
& 2 \\
10 & \\
20 & \\
\end{array}$ & 3 & 1 & 1 & $\begin{array}{r}1 \\
19 \\
3 \\
\end{array}$ & $\begin{array}{r}21 \\
31 \\
4\end{array}$ & $\begin{array}{l}1 \\
3 \\
1 \\
2 \\
\end{array}$ & $\begin{array}{l}3 \\
3 \\
\end{array}$ & $\begin{array}{l}363 \\
508 \\
107 \\
353 \\
345 \\
\end{array}$ & $\begin{array}{r}109 \\
100 \\
48 \\
191 \\
264 \\
\end{array}$ & $\begin{array}{l}472 \\
608 \\
155 \\
544 \\
609 \\
\end{array}$ & \begin{tabular}{|l|} 
VA \\
VA \\
VA \\
VA \\
VA \\
\end{tabular} & $\begin{array}{l}G \\
G \\
G \\
G \\
G \\
\end{array}$ & $\begin{array}{c}\text { VA } \\
\text { A } \\
\text { A }\end{array}$ & & \begin{tabular}{l|}
$\mathrm{C}$ \\
$\mathrm{C}$ \\
$\mathrm{C}$ \\
$\mathrm{F}$ \\
$\mathrm{F}$ \\
\end{tabular} & & & & \\
\hline & $\begin{array}{l}2 \\
2 \\
\end{array}$ & & $\begin{array}{l}2 \\
5 \\
\end{array}$ & 32 & & & $\begin{array}{l}10 \\
10\end{array}$ & $\begin{array}{l}10 \\
17\end{array}$ & & 5 & & & $\begin{array}{r}21 \\
2 \\
\end{array}$ & 4 & 1 & $\begin{array}{r}0 \\
0 \\
0 \\
194 \\
234 \\
\end{array}$ & $\begin{array}{r}1 \\
1 \\
0 \\
219 \\
59 \\
59\end{array}$ & $\begin{array}{r}1 \\
1 \\
0 \\
413 \\
293 \\
\end{array}$ & \begin{tabular}{|c|}
$R$ \\
R \\
B \\
VA \\
VA \\
\end{tabular} & $\begin{array}{l}P \\
P \\
G \\
G\end{array}$ & A & & $\begin{array}{l}\mathrm{C} \\
\mathrm{C} \\
\mathrm{C} \\
\mathrm{C} \\
\mathrm{C}\end{array}$ & & & & \\
\hline 2 & 2 & 10 & 10 & 3 & & & $\begin{array}{r}30 \\
1\end{array}$ & 27 & & & & 44 & & 1 & & $\begin{array}{r}308 \\
0 \\
5 \\
0 \\
0 \\
\end{array}$ & $\begin{array}{r}99 \\
1 \\
0 \\
0 \\
8 \\
\end{array}$ & \begin{tabular}{r|}
407 \\
1 \\
5 \\
0 \\
8 \\
\end{tabular} & \begin{tabular}{|l|} 
VA \\
R \\
R \\
B \\
F \\
\end{tabular} & $\begin{array}{l}\mathrm{G} \\
\mathrm{P} \\
\mathrm{M} \\
\overline{\mathrm{P}}\end{array}$ & $\begin{array}{l}\mathrm{P} \\
\mathrm{A} \\
\mathrm{C}\end{array}$ & & $\begin{array}{l}\mathrm{C} \\
\mathrm{C} \\
\mathrm{F} \\
\mathrm{F} \\
\mathrm{F} \\
\end{array}$ & & & & \\
\hline & 1 & 2 & 1 & & & $\begin{array}{r}5 \\
21 \\
\end{array}$ & & 1 & & 1 & & 1 & 1 & & & $\begin{array}{r}18 \\
14 \\
1 \\
0 \\
35 \\
\end{array}$ & $\begin{array}{r}7 \\
17 \\
0 \\
0 \\
91 \\
\end{array}$ & $\begin{array}{r}25 \\
31 \\
1 \\
0 \\
126 \\
\end{array}$ & \begin{tabular}{|c|} 
C \\
$C$ \\
R \\
B \\
VA \\
\end{tabular} & $\begin{array}{l}\mathrm{M} \\
\mathrm{M} \\
\mathrm{P} \\
\overline{\mathrm{M}}\end{array}$ & $\begin{array}{c}\text { A } \\
\text { VA }\end{array}$ & & $\begin{array}{l}\mathrm{F} \\
\mathrm{F} \\
\mathrm{F} \\
\mathrm{F}\end{array}$ & A & & & \\
\hline $\begin{array}{r}26 \\
1\end{array}$ & & & $\begin{array}{l}4 \\
2\end{array}$ & 68 & & & $\begin{array}{l}90 \\
32\end{array}$ & & & 5 & & 7 & 24 & & & $\begin{array}{r}0 \\
588 \\
0 \\
109 \\
0\end{array}$ & $\begin{array}{r}1 \\
258 \\
1 \\
1 \\
32 \\
0 \\
0\end{array}$ & $\begin{array}{r}1 \\
846 \\
1 \\
141 \\
0\end{array}$ & \begin{tabular}{|c|} 
R \\
VA \\
R \\
VA \\
B \\
\end{tabular} & $\begin{array}{c}\mathrm{P} \\
\mathrm{G} \\
\mathrm{P} \\
\mathrm{M} \\
-\end{array}$ & $\begin{array}{l}\mathrm{F} \\
\mathrm{A} \\
\mathrm{F}\end{array}$ & & $\begin{array}{l}\text { F } \\
\text { C } \\
\text { C } \\
\text { F }\end{array}$ & & & & \\
\hline $\begin{array}{l}4 \\
8\end{array}$ & & 11 & $\begin{array}{r}1 \\
1 \\
15 \\
1\end{array}$ & 1 & & $\begin{array}{c}1 \\
12 \\
7 \\
8\end{array}$ & 6 & & 6 & 3 & 30 & 3 & & & $\begin{array}{l}1 \\
1\end{array}$ & $\begin{array}{r}3 \\
25 \\
100 \\
92 \\
35\end{array}$ & $\begin{array}{r}5 \\
73 \\
28 \\
195 \\
67\end{array}$ & $\begin{array}{r}8 \\
98 \\
128 \\
287 \\
102\end{array}$ & \begin{tabular}{|l} 
F \\
VA \\
VA \\
VA \\
VA
\end{tabular} & $\begin{array}{l}P \\
G \\
G \\
G \\
G \\
G\end{array}$ & $\begin{array}{l}\text { VA } \\
\text { F } \\
\text { A } \\
\text { A } \\
\text { C }\end{array}$ & & $\begin{array}{l}\mathrm{F} \\
\mathrm{C} \\
\mathrm{F} \\
\mathrm{F} \\
\mathrm{A}\end{array}$ & $\begin{array}{l}F \\
F\end{array}$ & & & \\
\hline & & & $\begin{array}{r}13 \\
5 \\
6\end{array}$ & 3 & & 5 & $\begin{array}{r}22 \\
12 \\
110\end{array}$ & & & 2 & 1 & & & & 2 & $\begin{array}{r}110 \\
29 \\
0 \\
260\end{array}$ & $\begin{array}{rr}2 & 1 \\
71 & 1 \\
0 \\
202 & 4\end{array}$ & $\begin{array}{r}113 \\
100 \\
0 \\
462\end{array}$ & \begin{tabular}{|l} 
VA \\
VA \\
B \\
VA
\end{tabular} & $\begin{array}{c}164 \\
\mathrm{G} \\
\bar{G}\end{array}$ & $\begin{array}{c}\text { A } \\
\text { VA } \\
\text { C }\end{array}$ & G & $\begin{array}{l}\mathrm{C} \\
\mathrm{C} \\
\mathrm{C}\end{array}$ & $\begin{array}{l}\mathrm{C} \\
\mathrm{C}\end{array}$ & $F$ & $\mathbf{F}$ & \\
\hline
\end{tabular}




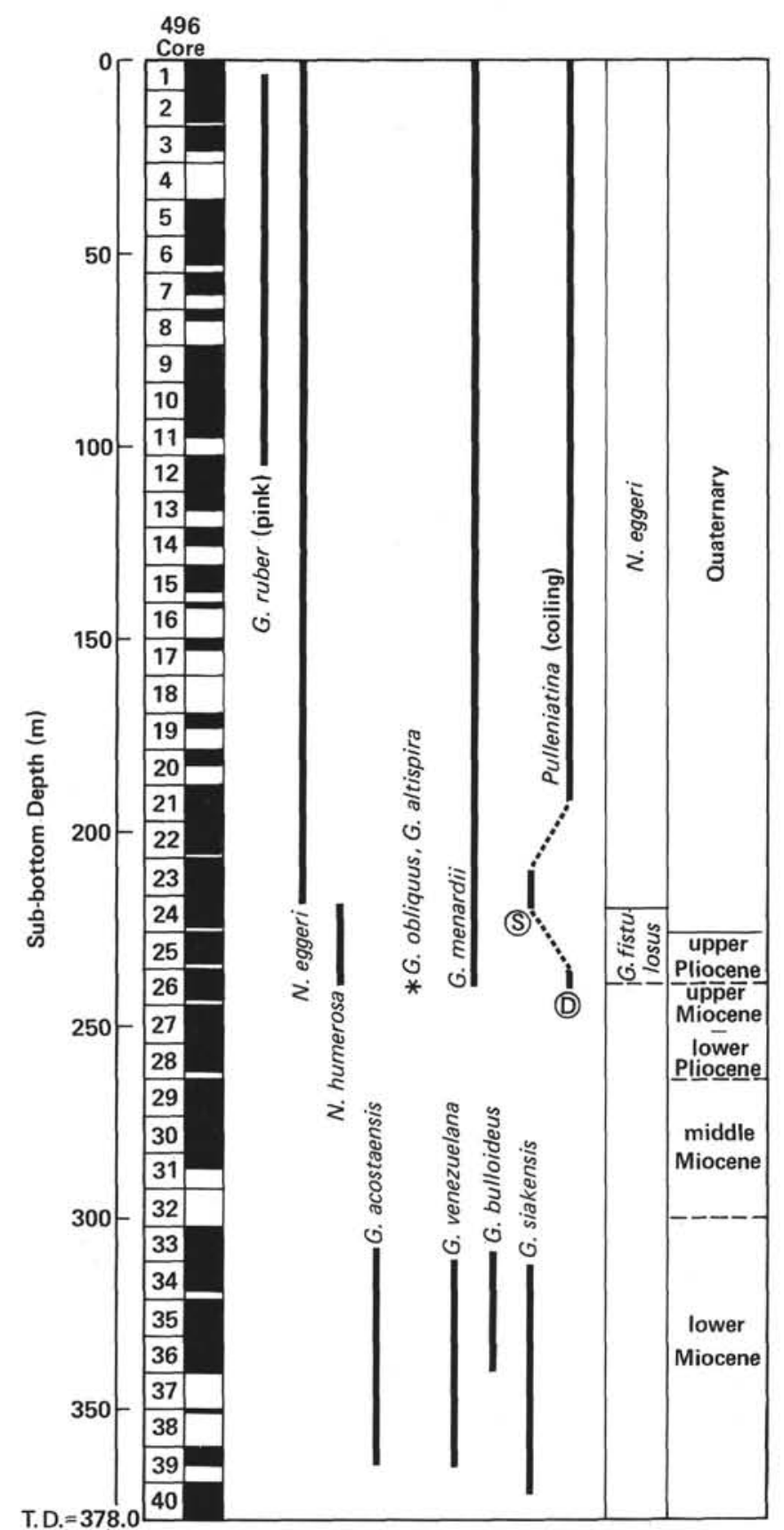

Figure 10. Range chart of planktonic foraminifers at Site 496. $(\mathrm{D}=$ dextral, $\mathrm{S}=$ sinistral coiling direction. The asterisk indicates the position of an isolated occurrence at the site.) 
Table 8. Planktonic foraminifers and other microconstituents at Site 496.

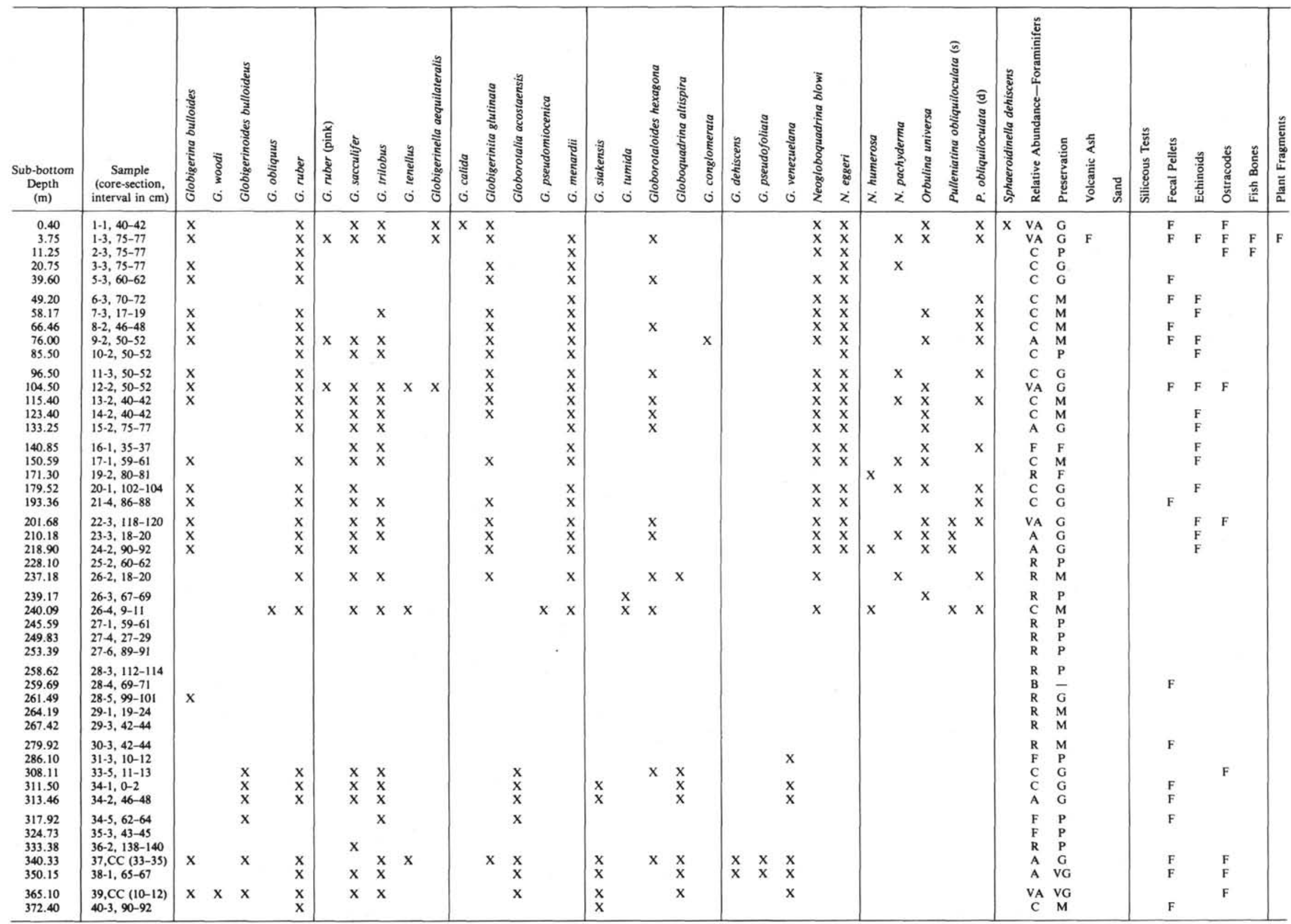




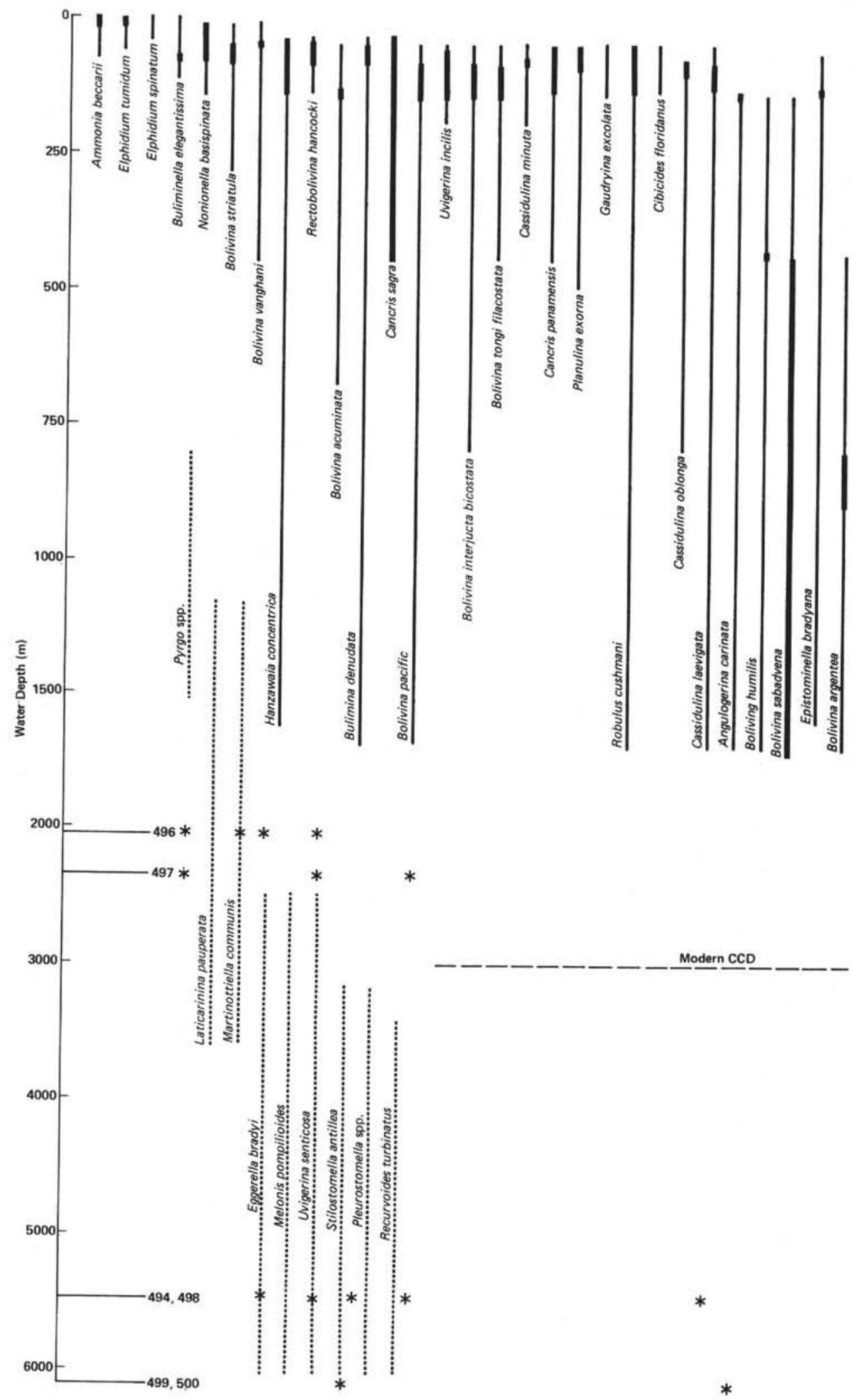

Figure 11. Ranges of selected benthic foraminifers from the Middle America Trench, slope, and shelf. (Data for shelf and upper slope from Bandy and Arnal [1957] and Smith [1964]; data for abyssal taxa from the Peru-Chile Trench study of Bandy and Rodolfo [1964]. Note the faunal changes coincident with the oxygen minimum at $500 \mathrm{~m}$ and the carbonate compensation depth [CCD] at about $3000 \mathrm{~m}$ water depth.) 
FORAMINIFERS OF THE MIDDLE AMERICA TRENCH

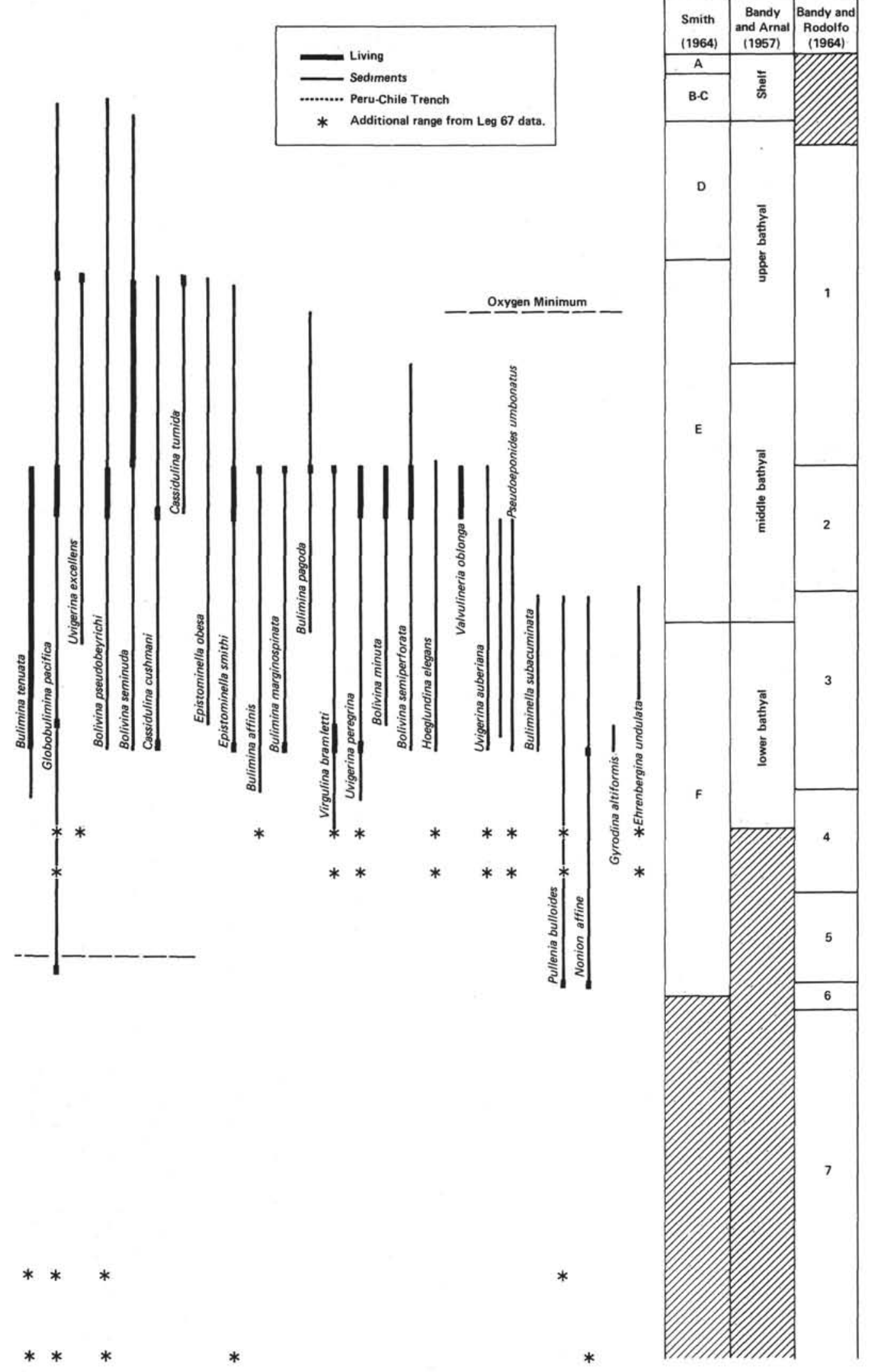

Figure 11. (Continued). 


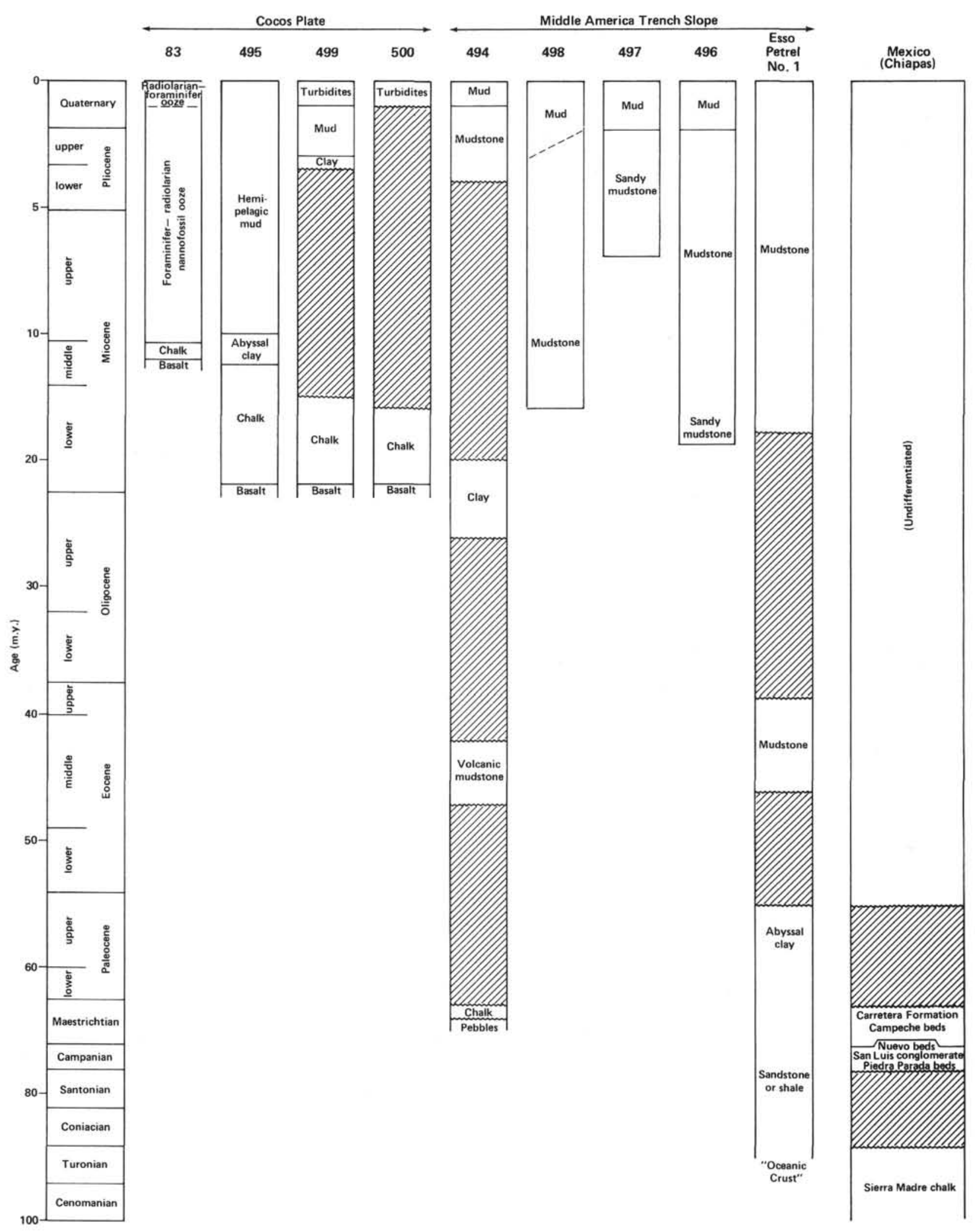

Figure 12. Correlation of deep drilling sites off Central America with published land sections (see Table 1 and Fig. 1 for locations). (Data sources: Esso Petrel No. 1 [Seely, 1979]; Guatemala [Vinson, 1962; van den Bold, 1963]; Costa Rica [Dengo, 1962; Henningsen, 1968]; Canal Zone [Woodring and Thompson, 1949; van den Bold, 1966; Bandy, 1970]; other sections after Weyl [1980 and references therein]; DSDP columns from site reports for Legs 9, 16, and 67.) 


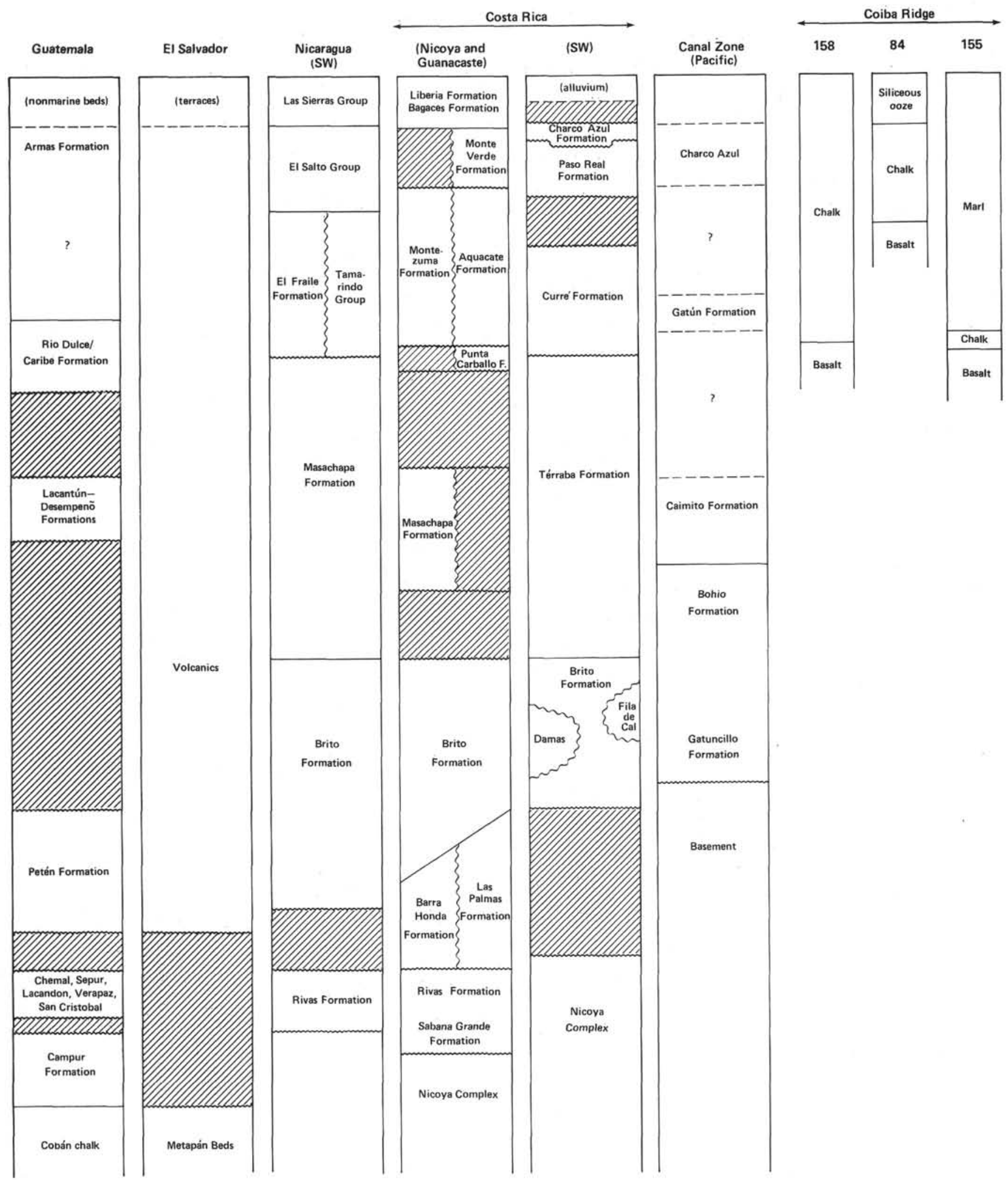

Figure 12. (Continued). 